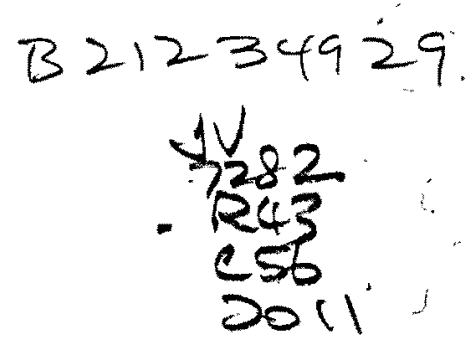

\title{
CANADA'S IMMIGRATION LOANS PROGRAM AND ITS \\ EFFECTS ON REFUGEES POST-IRPA
}

by

Sulyn Chow, BA, University of Calgary, 2009

\author{
A Major Research Paper \\ presented to Ryerson University
}

in partial fulfillment of the requirements for the degree of

\author{
Master of Arts \\ in the Program of \\ Immigration and Settlement Studies
}

Toronto, Ontario, Canada, 2011

$\leq$

(C) Sulyn Chow 2011 
I hereby declare that I am the sole author of this major research paper.

I authorize Ryerson University to lend this paper to other institutions or individuals for the purpose of scholarly research.

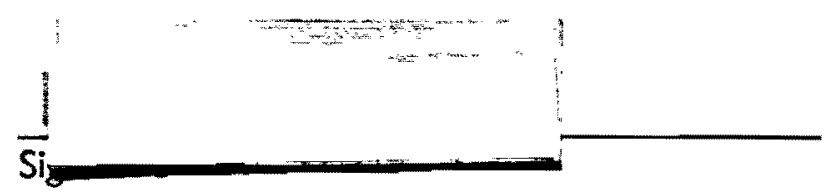

I further authorize Ryerson University to reproduce this paper by photocopying or by other means, in total or in part, at the request of other institutions or individuals for the purpose of scholarly research.

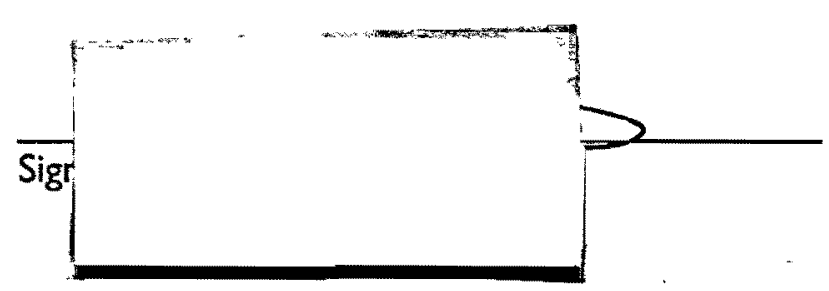




\title{
CANADA'S IMMIGRATION LOANS PROGRAM \\ AND ITS \\ EFFECTS ON REFUGEES POST-IRPA
}

\author{
Sulyn Chow \\ Master of Arts, 2011 \\ Immigration and Settlement Studies \\ Ryerson University
}

$\therefore \quad$ ABSTRACT

Canada is the only resettlement country that charges refugees for the resettlement expenses of their admissibility medical exam(s), travel documents, transportation and related administrative costs, and since 1995, monthly compounding interest. These costs are managed through the Admissibility and Transportation Loans, which are part of the greater Immigration Loans Program. The primary objective of this paper is to thoroughly and coherently explain the Immigration Loans Program and what it means to people arriving to Canada as refugees. The second objective is to examine the policy appropriateness of the Admissibility and Transportation Loans. Ultimately, it is concluded that the Immigration and Refugee Protection Act has shifted Canada's resettlement objectives in a more humanitarian direction, and that the Admissibility and Transportation Loans are evidence of a refugee policy that has not adapted to this change.

Keywords: Canadian Immigration Policy, Refugees, Transportation Loan, Resettlement, Advocacy

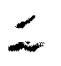




\section{ACKNOWLEDGEMENTS}

I would like to thank Dr. John Shields for acting as my supervisor, as well as Dr. Bryan Evans for being my second reader. Your insights were keen and much appreciated. I am grateful to Danno and my family for their enduring support throughout my academic quests. My appreciation also goes to $\mathrm{ClC}$ for granting me access to their subject-matter experts. Lastly, I thank each one of the people I know who have come to Canada as refugees: your determination is an inspiration to me. 


\section{DEDICATION}

This paper is dedicated to you, Mom.

your unwavering belief has enabled me to soar.

$\therefore$ 
SECTION I: INTRODUCTION I

SECTION 2: THE HISTORY OF CANADA'S REFUGEE POLICIES .3

I. EARLY CANADA'S AD HOC IMMIGRATION, (1775-1914). . .3

II. IMMENSE RESTRICTIONS OF WORLD WARS I \& II AND THE GREAT DEPRESSION, (1915-1945) 4

III. POST-WWII BEGINS POSITIVE ATTITUDE SHIFT TOWARDS REFUGEES, (1946-1948)_..... 5 IV. THE BEGINNINGS OF A STRUCTURED IMMIGRATION SYSTEM \& INTRODUCTION OF THE ASSISTED PASSAGE LOAN, (1948-1950) .7

V. THE DEVELOPMENT OF CANADA'S REFUGEE POLICY (1951-Present) ....................................8

An End to White Canada Immigration Policies, 1962....................................................................

Canada Ratifies UNHCR Convention and Protocol Relating to the Rights of Refugees, 1969 ...9

The Establishment of an Official Immigration and Refugee System, 1976 ..........................................9

The Immigration and Refugee Protection Act, 2001............................................................................10

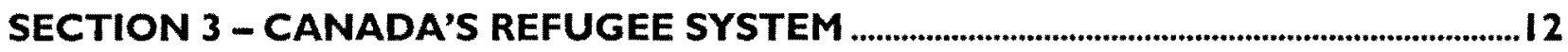

I. THE UNITED NATION'S THREE-PRONGED DURABLE REFUGEE SOLUTION.......................12

II. CANADA'S DEFINITION OF REFUGEE

III. THE STRUCTURE OF CANADA'S REFUGEE SYSTEM ..............................................................15

In-Canada Asylum Program .............................................................................................................................15

Refugee And Humanitarian Resettlement Program...........................................................................15

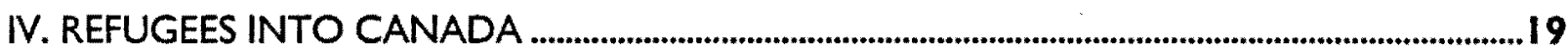

SECTION 4: THE IMMIGRATION LOANS PROGRAM'S BASICS

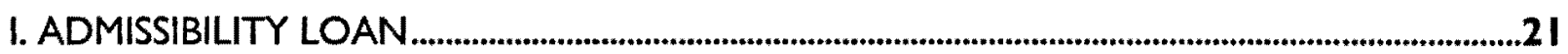

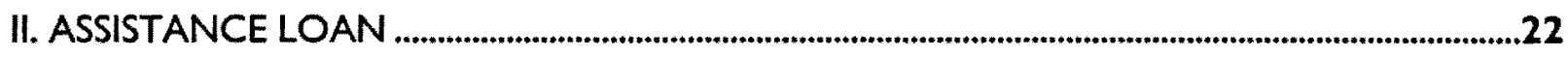

Basic Needs Of Life......................................................................................................................................22

Basic Household Needs .....................................................................................................................................22

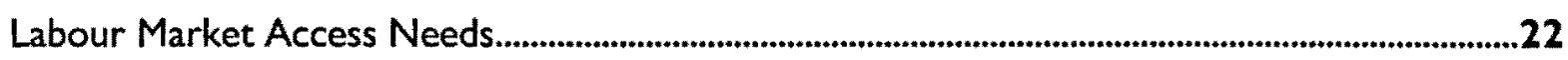

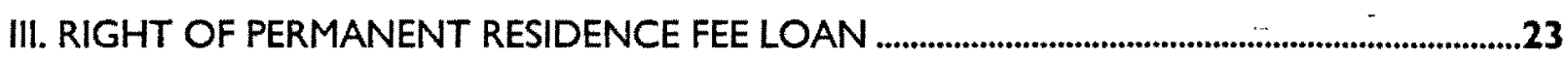

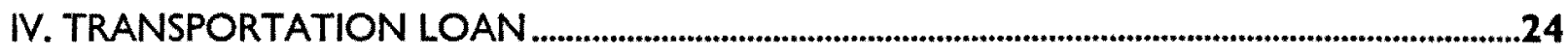

The International Organization Of Migration ..............................................................................................24 
SECTION 6: THE IMMIGRATION LOAN DISCOURSE .....................................................28

I. CONFLATION OF ADMISSIBILITY AND TRANSPORTATION LOANS ......................................28

$\therefore \quad$ II. THE VARIOUS IMPACTS OF THE IMMIGRATION LOANS .........................................................29

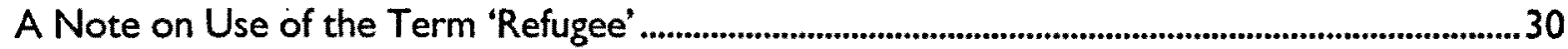

The Loans Affect Refugees Differently Depending on Sponsorship Arrangement ..........................31

SECTION 7: FINANCIAL DETAILS OF THE IMMIGRATION LOAN .................................33

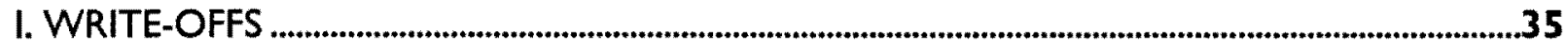

II. REPAYMENT SCHEDULE

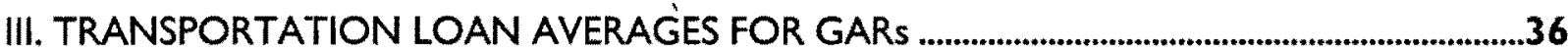

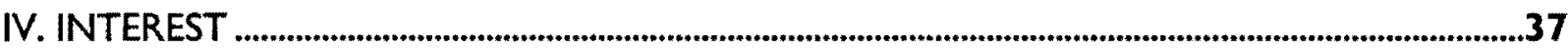

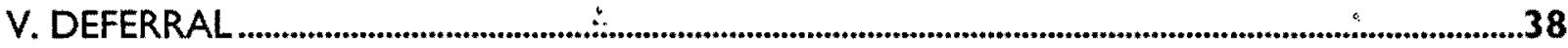

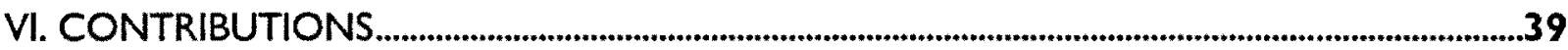

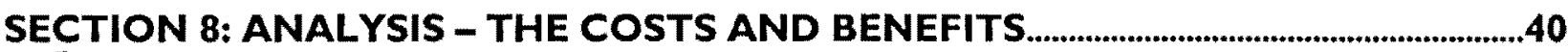

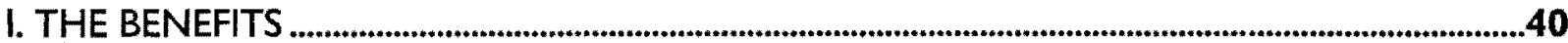

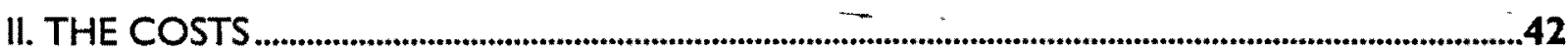

The Canadian Council For Refugees ................................................................................................................42

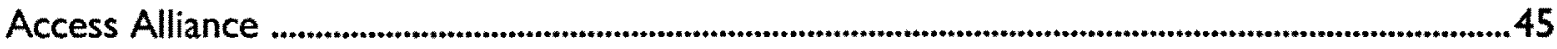

Surrey, British Columbia ........................................................................................................................................4

iii. THE FUTURE OF THE ADMISSIBILITY AND TRANSPORTATION LOANS .............................50

SECTION 9: CONCLUSION ............................................................................................. I 


\section{LIST OF TABLES}

Table 3.1: Refugees by Type into Canada, 2006-2010

Table 4.I: Comparison of IOM and Regular Price Airfares to Toronto in 2005

Table 7.I: Financial Overview of Immigration Loans Program

Table 7.2: Immigration Loan Repayment Schedule

Table 7.3: Average Loan by Family Size for Government-assisted Refugees, 2005-2009

Table 7.4: Interest Schedule for Immigration Loans

Table 8.I: Rudimentary Calculation of Immigration Loans Program's Financial Return 
CCR Canadian Council for Refugees

- CIC Citizenship and Immigration Canada

CBR Community Based Research

DFAIT Department of Foreign Affairs and International Trade

FCM Federation of Canadian Municipalities

GAR Government-Assisted Refugee

GOC Government of Canada

IRPA Immigration and Refugee Protection Act

IRPR Immigration and Refugee Protection Regulations

ICRC International Committee of the Red Cross

IOM International Organization for Migration

JAS Joint Assistance Sponsorship

LICO Low Income Cut-Off

PSTD. Post-Traumatic Stress Disorder

PSR Privately Sponsored Refugee

RSTP Refugee Sponsorship Training Program

RAP Resettlement Assistance Program

ROLF Right of Landing Fee

SPO Service Providing Organization

UBCM Union of British Columbia Municipalities

UN United Nations

UNHCR United Nations High Commissioner for Refugees 
Of the world's twenty-two countries that accept refugees for resettlement, Canada is the only one that recoups a triad of expenses incurred through resettlement: the admissibility medical exam and travel documents; all transportation and related administrative costs; and since 1995, monthly compounding interest after a period of one to three years. The policy mechanisms through which the Canadian government covers and reclaims these expenses are the Admissibility and Transportation Loans. These two loans are components of the greater Immigration Loans Program.

This paper seeks to fulfill two objectives. The primary aim is to fill a gap in the literature by creating a document that thoroughly and coherently explains the Immigration Loans Program and what it means to newcomers arriving to Canada as refugees. The second purpose is to examine the policy appropriateness of the Admissibility and Transportation Loans; more specifically, whether or not they are a suitable mechanism for refugee resettlement in the context of the 2001 Immigration and Refugee Protection Act (IRPA).

Prior to IRPA, refugees were selected from abroad based upon their ability to successfully establish and contribute to the Canadian economy. Above all others, applicants with the most advanced education, language proficiencies, and skill sets were selected for resettlement into Canada (Hiebert, 2009, p. 9). One striking tenet that IRPA introduced was an about-face change in the way that refugees were selected abroad: from pragmatic to humanitarian. For the first time in Canada's history, those who were in the greatest need of protection came to be explicitly prioritized over those who would most readily contribute economically (CIC, 2009a, s. 5).

"Knowledge is mostly dual use. It can be deployed by social forces of both dominance and emancipation" (Chimni, 2009, p. 14).

The binary nature and potential of knowledge creation has been regarded throughout this analysis of the Immigration Loans Program. Striking a balanced perspective while addressing this issue has been challenging at times, for there exists an innate conflict in the way that refugee issues tend to be perceived. Hardy and Phillips (1999) best encapsulate this tension in their discussion about the discursive struggle in the Canadian refugee system. They precisely identify the conflict as that between paternalism, which regards refugees as needing care, and empowerment, which promotes a perception of refugee's being self-reliant and independent (p. 7). 
This tension between paternalism and empowerment, and the problems with arguing solely from either pole is extremely pertinent to the Admissibility and Transportation Loans. To illustrate, paternalistic arguments generally hold that the loans are too burdensome for newcomers and that they act as impediments to integration. The problem with such arguments is that they ignore and undermine the success stories of those who arrive as refugees, work hard to pay off their loans, and who "successfully" transition into their new Canadian lives. Emphasizing the burdensome aspect of the loan also draw attention away from the tremendous strength displayed by individuals who manage the navigation of refuge in a third country.

On the other hand, empowerment arguments are equally flawed in their tendency to focus on the loans' high repayment rate of $91 \% 1$, and frame them as simply yet another condition to be overcome in the process of resettlement. The primary grievance here is against the inattention paid to the sacrifices made and opportunities lost in pursuance of repaying the loans. This paper acknowledges that the Immigration Loan affects a wide spectrum of people in a variety of ways, and does not seek to identify, numerate, or catalogue these experiences. Rather, its purpose is to take a macro approach and create a balanced document that acknowledges both the challenges, as well as the strengths, relational to the loans.

This paper is comprised of eight sections divided into two parts. The first half seeks to provide the reader with a factual foundation of the Immigration Loans Program's structure and evolution. This is achieved through a discussion of Canada's history with refugees in section two, Canada's refugee system in section three, and the component parts of the Immigration Loans Program in section four. The second part of the paper analyzes the details of the loans and its effects on refugees. Section five compares Canada's position within the international context, section six examines the Immigration Loans' discourse, and section seven explicates the financial details. Lastly, section eight analyzes the loans' costs and benefits.

\footnotetext{
1 This figure was originally calculated upon a historic analysis of pre-1995 loans. A 2005 internal audit on the Immigration Loans Program found that a subsequent analysis of the loan repayments from 1995-1999 yielded similarly high repayment rates. It is unclear whether the currently quoted $91 \%$ repayment rate has been recalculated to capture post-IRPA cohorts.
} 


\section{SECTION 2: THE HISTORY OF CANADA'S REFUGEE POLICIES}

Canada has not always enjoyed its current international reputation as a welcoming and generous nation towards refugees. In reality, the policy journey up until this point has been slow and mostly reactionary in nature. To fully comprehend the Immigration Loan and its impacts, one must have a sense of the context from which it originated. The proceeding section provides the historical background necessary to understand how Canada's management of refugees has evolved. This is achieved through a discussion of the following five stages: early Canada's ad hoc immigration (1775-1914); the immense restrictions of World Wars I \& II and the Depression (1915-1945); postWWII's positive attitude shift towards refugees (1946-1948); a more structured system and the Assisted Passage Loan (1948-1950); and the development of Canada's refugee policy (1951present).

\section{EARLY CANADA'S AD HOC IMMIGRATION, (1775-1914)}

Migration to Canada during this early period was dominated by agricultural settlement. The land was unbroken and arduous, and the seasons were extreme for those unprepared; it was an inhospitable place and very few sought its refuge. Pre-dating Confederation, the first, and most significant, wave of political refugees were the 40,000 to 50,000 British Loyalists who arrived throughout the American War of Independence (1775-1784) (Knowles, 2007, p. 36). These refugees resettled into parts of the land that were already somewhat established by settlers: approximately 35,000 loyalists settled in the Maritimes, 2,000 went to Quebec, and the remaining 7,500 moved into Ontario (Wilson, 1988, p. 68).

After Confederation, Canada sporadically offered reprieve to a few endangered groups of people, such as the religiously persecuted Prussian Mennonites from Russia in 1871, and the Russian Jews who were escaping the pogroms in 1881 (Kelly \& Trebilcock, 2000, p. 72-74). Importantly, the solicitation of these two religiously persecuted groups by the Canadian government was not based entirely on humanitarian notions. In truth, it was their respective reputations as hard-working agriculturalists and knowledgeable entrepreneurs, as much as their plight that spurred the government into offering attractive land inducements and religious concessions (Kelly \& Trebilcock, 2000, p. 76). 
The lax immigration procedures that these two particular Mennonite and Jewish groups encountered while entering Canada are also important to note, for they reflect the undefined status of refugees during that period. Unlike refugees today, who are processed through distinct and separate channels, those two groups were funneled into the country like other migrants: their movement was largely unregulated, and they were not designated into a special class of arrivals (Jones \& Baglay, 2007, p. 2). A formal system of entry for refugees would not be forthcoming for another century.

After Confederation, immigration was identified, by Prime Minister Macdonald's National Policy, as one of the four major potential drivers of economic growth ${ }^{2}$ (Kelly \& Trebilcock, 2000, p. 61). Canada's immigration regulations started to become more centralized and comprehensive as a result (Jones \& Baglay, 2007, p. 3); however, they remained mostly passive ${ }^{3}$ until 1896 when Canada's new Minister of the Interior, Clifford Sifton, began an aggressive campaign to recruit immigrants. Between 1896 and 1914, Canada's population grew by a staggering $43 \%$, as more than three million new immigrants arrived (Knowles, 2007, p. 124).

\section{IMMENSE RESTRICTIONS OF WORLD WARS I \& II AND THE GREAT DEPRESSION, (1915-1945)}

The bustling period of incomers at the turn of the century was quickly followed by a dramatic fall in immigration levels as increasingly strict, racially bounded, and protectionist restrictions were passed into legislation. From 1915 to 1945, as the world coped with two World Wars and an unprecedented economic depression, Canada decidedly turned against almost all potential immigrants and refugees. In fact, during this low period, Canada was so unwilling to help those in need that it went beyond rejecting applicants and actually began deporting immigrants who were 'burdening' the country's coffers (Knowles, 2007, p. 143). Between 1930 and 1935, Ottawa deported 30,000 immigrants who were receiving government assistance back to Europe (Francis, Jones, \& Smith, 2000, p. 292).

In addition to being anti-immigration, Canada's attitude was also rigorously anti-refugee: this was clearly demonstrated in two ways. For one, by the 1930s Canada had implemented such stringent entry regulations that it became nearly impossible for refugees to gain entry (Knowles, 2007, p. 144). In 1931, increasingly stringent legislation was passed to accompany the already restrictive

\footnotetext{
${ }^{2}$ Immigration as generator of economic growth has continued to be a theme up to present day (CIC, 2010a, p. 6).

${ }^{3}$ One dastard exception to this was the Chinese head-tax (1885) and its subsequent amendments (Knowles, 2007, p. 71).
} 
1919 Continuous Journey legislation and the 1914 Contract Labour Regulation (Knowles, 2007, p. 144). The 1931 legislation stated that only agriculturalists with means, immediate relatives of Canadians, and those from America and the United Kingdom with sufficient capital were permitted

- to enter Canada (Kelley \& Trebilcock, 2000, p. 222).

The second, and one of Canada's most infamous demonstrations of its anti-refugee stance was the refused docking of the S.S. St Louis, which held 907 Jewish refugees (Abella \& Troper, 1991, p. 63). After being denied refuge in Cuba, various Latin American countries, the United States, and finally Canada, this "voyage of the damned" was left with no alternative but to sail back to Europe where the majority of passengers faced certain death (Abella \& Troper, 1991, p. 63; Jones \& Baglay, 2007. p. 6).

It should be noted that the government did occasionally bend to the intense lobbying efforts of dedicated Canadians to admit small groups of people seeking refuge ${ }^{4}$. However, Canada's overall stance remained overwhelmingly anti-refugee (Knowles, 2001, p. $139 \&$ 144). Knowles (2007) starkly summarizes Canada's actions at this time:

When she was most required to show compassion, Canada shut herself off from the world and strenuously fought any attempt by desperate refugees, especially Jewish refugees, to breach the wall of restrictive legislation... (p. 144)

In a similar tone, Abella \& Troper (1991) noted that during this period Canada's admittance of refugees was "arguably the worst of all possible refugee receiving states" (p. xxii). From 1933 1945, Canada accepted fewer than 5,000 Jewish refugees (Abella \& Troper, p. xxii). Fortunately, the negative outcomes of Canada's intolerant policies were taken as lessons, and a fundamental shift in the attitudes towards refugees slowly began to emerge after the end of the Second World War (Kelley \& Trebilcock, 2000, p. 310).

\section{POST-WWII BEGINS POSITIVE ATTITUDE SHIFT TOWARDS REFUGEES, (1946-1948)}

Throughout the war years, the Canadian government and public were largely in agreement about the restrictive nature of immigration policies; however, after the Second World War ended opinions between the two began to diverge (Kelley \& Trebilcock, 2000, p. 307). As stories of the atrocities

4For example, the efforts of Lillian Freiman in 1920 to bring over 150 orphaned Jewish children from the Ukraine (Knowles, 2007, p. 139). 
filtered across the ocean, Canadian citizens became increasingly cognizant of the damage that ethnocentric thinking could yield, and as a result, public expressions of racial intolerance became increasingly unacceptable (Kelley \& Trebilcock, 2000, p. 310). Calls from the public to create more humane immigration policies began gaining in frequency and strength.

To demonstrate, some lobbyists began going beyond humanitarian notions, attempting to sway the government with economic arguments (Knowles, 2007, p. 156 \& 158). They contended that allowing more refugees into Canada would increase the population, which would lead to a larger market, which would translate into larger economies of scale, thereby strengthening Canada's economy (Knowles, 2007, p. 156). Some other pro-immigration advocates attempted argumentation along national security lines. They asserted that the admittance of more refugees would result in more dispersed settlement across the land, which would ultimately strengthen Canada's sovereignty claims (Holmes, 1979, p. 101; Knowles, 2007, p. 156).

In spite of these arguments, the anticipation of a post-war depression, like that which followed WWI, anti-Semitism, and a whole host of latent and protectionist fears kept the Canadian government from immediately heeding the public's calls. At that time in Canadian history, immigration statistics did not distinguish between immigrants and refugee incomers. As such, the government was able to delay its response to the public by asserting that that more refugees had actually been admitted into the country than it appeared (Kelley \& Trebilcock, 2007, p. 258). For two years the government continued to stall on lowering immigration barriers, preferring instead to donate substantial funds towards Europe's reconstruction and rehabilitation efforts (Knowles, 2007, p. 155-6).

Finally on May 1, 1947, the Prime Minister bowed to public and international pressure (Knowles, 2007, p. 162). Mackenzie King hedged his statement about relaxing immigration levels with the inclusion of references to "absorptive capacity" and Canada's right to discriminate (Kelley \& Trebilcock, 2000, p. 312; Knowles, 2007, p. 163). Nevertheless, it signified an official and definite change of attitude towards Europe's refugees and displaced persons (Knowles, 2007, p. 164). 
-The Second World War brought forth a great number of lessons and awareness'. One significant aspect to arise was the beginnings of a refugee discourse. Up to that time, Canada, and many other countries, did not differentiate between refugees and other migrants, and tended to admit persecuted groups in non-standardized and ad hoc fashions. The two World Wars forced the world to recognize, acknowledge, and begin to define the experiences of those displaced by conflict.

From this point in time, Canada's actions regarding immigration started to become more effectively structured and less reactionary. This period is also notable, for it established many of the manners in which refugee policy is conducted today. In regards to refugees, there are two particular courses set by this period that are still in evidence today: the voices that influence refugee selection abroad and the Transportation Loan.

As to the first similarity, soon after Mackenzie King's 1947 pivotal speech, legislation was passed to admit 45,000 European refugees (Knowles, 2007, p. 165). To orchestrate this endeavor, the government delegated five teams comprised of immigration, labour, security, and medical officials to Europe. Their mandate was to travel through various displaced persons' camps, and to interview and select able-bodied people for resettlement: preferably strong single males (Holmes, 1979, p. 101, quoted in Knowles, 2007, p. 165). The composition and selection criteria of this 1947 team are intriguing, for they have effectively served as a template that guides refugee selection in the present day.

To illustrate, the resemblance between the 1947 team's composition, and those who currently tasked with selecting refugees from abroad is striking. While Canada no longer dispatches the four Canadian officials (immigration, labour, medical, and security), it does employ equivalent representatives who interview and conduct examinations on its behalf from Citizenship and Immigration Canada, the United Nations (UN), and the International Organization of Migration. Today, these officials are charged with determining the ability of refugees to successfully settle into Canada (immigration and labour equivalents), the existence of any medical conditions (medical), and the passing of criminal and security checkśs (security). 
A second likeness to today began in 1950, when the Department of Citizenship and Immigration was created to replace the Immigration Branch of the Department of Mines and Resources (Kelley \& Trebilcock, 2000, p. 323). Tasked with increasing immigration, this new department soon noted the barrier that coveted British laborers were facing in travelling to Canada. As a result of the pound's devaluation in 1949, transportation costs had skyrocketed and the majority of would be migrants were unable to afford the sea passage to Canada (Kelley \& Trebilcock, 2000, p. 323).

In response to this predicament, the department solicited cabinet for a $\$ 9$ million dollar fund that would loan monies to British immigrants "whose services were urgently required" to help cover part or all of the cost of their transportation (Department of Foreign Affairs and International Trade [DFAIT], 1955, p. 1). The request was granted and in 1950 the Assisted Passage Loan Fund was created. The three provisions of the loan were that the funds would be granted to heads of families and single persons, that the amounts were to be repaid by monthly installments within a period of two years, and that the repayment installments would be calculated according to the person's earnings and family circumstances (DFAIT, 1955, p. 2). This Assisted Passage Loan Fund is the basis of what has evolved into the Immigration Loans Program today.

\section{THE DEVELOPMENT OF CANADA'S REFUGEE POLICY (1951-Present)}

Over the last half of the twentieth century, Canada underwent a slow, but monumental shift in its attitude towards accepting refugees. From the 1950s to the mid-1960s there were incremental improvements to the immigration system; however, policy pertaining specifically to refugees remained mostly ad hoc and myopic (Jones \& Baglay, 2007, p. 7; Kelley \& Trebilcock, 2000, p. 363). It was after the 1970s that Canada's refugee system began to more fully develop its own distinct structure. The four most punctuating events for refugees over the course of this time were the cessation of White Canada immigration policy in 1962, the signing of the Refugee Convention and Protocol in 1969, the 1976 Immigration Act's delineation of Canada's immigration system, and ratification of the 2001 Immigration and Refugee Protection Act.

\section{AN END TO WHITE CANADA IMMIGRATION POLICIES, 1962}

Although the 1952 Immigration Act was more sympathetic in nature than previous acts, it still retained a strong racial bias (Jones \& Baglay, 2007, p. 7). Canada's Year Book from 1930 clearly outlined the racial preference of acceptable newcomers with British and Americans topping the list, 
followed by North Europeans, then Central Europeans, and then by Southern and Eastern Europeans (quoted in Kelley \& Trebilcock, 2000, p. 442). At the bottom of the list were Jews followed lastly by 'Orientals' and 'blacks'. This racial hierarchy overtly prevailed for decades, but became increasingly challenged over time.

By the 1960s, Canada's economic needs for labour and ideological shifts had culminated together, necessitating a change in the manner and countries that migrants were selected from (Jones \& Baglay, 2007, p. 8). These needs were addressed in 1962 with the implementation of regulations that ended racial discrimination as one of the major features of Canada's immigration policy (Knowles, 2007, p. 187). Canada became the first major resettlement nation to eschew a racially discriminatory immigration policy with its assertion that if migration applicants were able to demonstrate the possession of education, skills, and work experiences that Canada was seeking, then they would be considered for admission regardless of race, colour, or ethnic origin (Knowles, 2007, p. 187). This lessening of racial and geographical discrimination ultimately eased the way for non-White, non-European refugees to gain admission into Canada (Knowles, 2007, p. 211).

\section{CANADA RATIFIES CONVENTION AND PROTOCOL RELATING TO THE RIGHTS OF REFUGEES, 1969}

The year 1969 also signified an extremely important point for refugees because it was the year that Canada finally ratified the 1951 Geneva Convention Relating to the Status of Refugees and the related 1967 Protocol. In assenting the Refugee Convention and Protocol, Canada agreed, among many other things, to uphold the definition of Convention refugee and the principle of nonrefoulement. Since non-refoulement holds that no person shall be expelled or returned against their will to a country in which they fear threats to their life or freedom (United Nations High Commissioner for Refugees (UNHCR), 1967, p. 3), Canada subsequently began the development of its in-land refugee system.

\section{THE ESTABLISHMENT OF AN OFFICIAL IMMIGRATION AND REFUGEE SYSTEM, 1976}

In the early 1970s, it was clear that Canada's immigration system was in dire need of further reform. The new allowance for visitors to apply for landed immigrant status after arrival into Canada, in conjunction with the fact that anyone denied this status could apply for an appeal, quickly lead to an enormous backlog (Knowles, 2007, p. 200). The Canadian government responded to this accumulation by initiating a substantial review of its immigration policy. 
After considerable consultation with the provinces, public, and interested organizations, the government passed its most comprehensive act up until that date. For the first time in Canada's history, the fundamental principles and objectives of immigration were outlaid along with a clear management structure (Kelley \& Trebilcock, 2000, p. 390). Migrants were classed as independent, family, or humanitarian, and the humanitarian class was further divided into Government-assisted refugees, privately sponsored refugees, and those arriving under special programs (Knowles, 2007, p. 208; Jones \& Baglay, 2007, p. 10). This separation of refugees into their very own admissions class was a significant measure, for it standardized the acceptance of refugees and moved away from the previously arbitrary admissions processes. This act also enshrined the formal recognition of Canada's obligations under the UNHCR Refugee Convention and Protocol (Knowles, 2007, p. 209).

\section{THE IMMIGRATION AND REFUGEE PROTECTION ACT, 2001}

The final milestone of this period was the enactment of the Immigration and Refugee Protection Act (IRPA) and its corresponding Regulations in 2002. In regards to refugees, this act introduced both heavily criticized and praised elements. Some of the points most criticized by refugee advocates were the reduction of deciding members at in-land refugee claimant hearings from two to one, the mandatory referrals for overseas refugee applicants, and the increased power given to immigration officials to arrest and detain (Jones \& Baglay, 2007, p. 21).

As to positives, the IRPA encompassed a powerful change in its attitude towards the humanitarian selection of refugees: it clearly moved away from admitting refugees with the greatest potential to economically contribute, towards those in the greatest and most urgent need of protection (CIC, $2010 \mathrm{~h}$ ). At this time, resettled refugees became exempt from inadmissibility due to financial needs, or from excessive demands of medical and social services (CIC, 2011b, p. 8). As Daniel Hiebert (2009) noted, Canada began to bypass those refugees with advance educations and skills, in favour of admitting highly vulnerable populations, "such as persons with disabilities and single mothers and their children" (p. 9).

Canada's relationship with refugees is one that has grown very slowly, but with certainly. Today, Canada has the highest per capita permanent resettlement rate, and is the second largest receiver of refugees for resettlement (Orr, 2004, p. 22). It is also commended by the United Nations not only for its acceptance of refugees from among the more vulnerable populations, but also for it 
willingness to settle urgent protection cases and those with high medical needs (Citizenship and Immigration Canada (CIC), 2011b, p. 7). A discussion of Canada's refugee system will now follow. 
One fundamental difference between immigrants and refugees is that immigrants exhibit agency in their decision to permanently settle in another country, while refugees are forced to flee their homes and resettle elsewhere (CIC, 2011e). The circumstances under which refugees and displaced persons are forced to migrate vary from immigrants, as do their routes into Canada; as such, Canada has a system that has evolved to specifically manage the migration of refugees. The ensuing section will describe this system by, firstly, identifying Canada's role in the wider context of the United Nations' solution to the international refugee crisis. Secondly, it will examine Canada's broadened definition of refugee. Thirdly, the practicalities of the refugee system will be detailed. Lastly, some of the most recent refugee settlement figures will be outlined to provide wider context to Canada's contemporary refugee system.

\section{THE UNITED NATION'S THREE-PRONGED DURABLE REFUGEE SOLUTION}

The United Nations has identified three complementary solutions, known internationally as "durable solutions", for resolving the international refugee situation: voluntary repatriation, local integration, and resettlement (UNHCR, 2011c, p. 28). Voluntary repatriation is considered the most preferable solution, and occurs when a refugee returns to their country of origin in safety and dignity, based upon a free and informed decision (p. 31). The local integration solution is the most common; it grants refugees the permanent right to remain in the country of asylum, and to integrate legally, economically, and socially. The third solution, resettlement, is the process whereby refugees are selected and transferred from a country of asylum to a third state that has agreed to admit them and guaranteed permanent resident status with the opportunity for citizenship (p. 36).

Canada contributes towards ameliorating the international refugee situation through the third solution of resettlement (Pressé \& Thompson, 2008, p. 95). According to the United Nations' 2010 Global Trends report, there are approximately 15.4 million refugees worldwide 5 (p. 38), Of this refugee population, last year twenty-two nations resettled 98,800. The United States has the largest program, which resettled a commendable 71,400 in 2010 (U.S. Department of State, 2011). Canada accepts the second largest amount of resettled refugees, between 8,000 and 13,000

${ }^{5}$ This number includes Convention refugees, those in "refugee-like" situations, and asylum seekers with pending cases (UN, 2011a, Table 1, p. 38). 
annually (CIC, 2010b), and is the highest receiver per capita (Hyndman, 2009, p. 255; Orr, 2004, p. 22). In 2009, Canada accepted 12,461 refugees for resettlement (CIC, 2010a), and since World War II it has accepted more than 750,000 Convention refugees and persons in "refugee-like" situations (CIC, 2009a, p. 12).

The UN Resettlement Handbook (2011) appreciates the efforts that resettlement countries make, and highlights three important functions that this third solution serves (p. 36). Resettlement contributes both towards international protection and as a durable solution for those who are unable to repatriate and who are denied basic human rights in their first country of refuge. It is also a tangible way for countries to show international solidarity and a sharing of responsibility (p. 36). The Canadian government concurs, stating that its refugee policy is founded upon a humanitarian basis (CIC, 2010e, p. 6).

\section{CANADA'S DEFINITION OF REFUGEE}

Canada defines 'refugee' in one of two ways. The first 'traditional' definition is of Convention Refugee, which refers to the 1951 United Nation's Geneva Convention and its 1967 Protocol Relating to the Status of Refugees (hereafter called Refugee Convention). According to the Refugee Convention, which Canada ratified in 1969 and embedded into the 2001 Immigration and Refugee Protection Act, a Convention Refugee is a person who has fled their country of nationality or habitual place of residence and is unable or unwilling to return, due to a well-founded fear of persecution for reasons of race, religion, nationality, membership in a particular social group, or political opinion (IRPA, 2001, Article 96; UNHCR, 1967, Article 1).

Canada has broadened its interpretation of refugee beyond the traditional definition of Convention Refugee to include a second category, Humanitarian-Protected Persons Abroad class (CIC, 2010e, s. 7.26). This class encompasses two subsets: Country of Asylum class and Source Country class (CIC, 2010e, s.7.26). People in the Country of Asylum class do not fully meet the definition of Convention Refugee, but have equally well founded fears of torture, risk to their life, or risk cruel and unusual treatment or punishment (IRPA, 2001, Article 97). These people are informally called "persons in need of protection", and their situations are considered "refugee-like" (CIC, 2010e, p. 6). Persons in need of protection are often serfously affected by events such as civil war, armed conflict, and massive violations of human rights (CIC, 2010h). 
The second set of refugees under the Humanitarian-Protected Persons Abroad class is the Source Country Class. ${ }^{6}$ This class is distinct because it is the only instance in which people can apply for refugee status from within their country of citizenship or habitual place of residence (CIC, 2010e, s.7.44). Persons fall into this category for one of three reasons. One, they have well-founded fears, like Convention refugees, based on their race, religion, nationality, political opinion, or membership in a political group. Two, they have been detained or imprisoned for an act that, in Canada, would be considered a freedom of thought or legitimate exercise of civil rights pertaining to dissent or trade union activity. And three, they are seriously affected by civil war or armed conflict (CIC, 2010e, s. 7.44). This class was introduced in 1997 and has designated a total of ten countries since that time. The current six source countries, Columbia, Democratic Republic of Congo, El Salvador, Guatemala, Sierra Leone, and Sudan, were designated in 2001 (CIC, 2011c).

In sum, refugees as defined in Canada are either Convention Refugees, or Humanitarian-Protected Persons Abroad. Convention Refugees are classified according to the 1951 United Nations Convention and 1967 Protocol, and Humanitarian-Protected Persons Abroad are either Country of Asylum or Source Country class. Humanitarian-Protected Persons Abroad are refugees who are in great danger, but do not meet the traditional criterion of Convention Refugee or are inside the countries that they wish to flee. Canada's wider immigration system accepts immigrants through three broad classes: skilled, family, and refugee. Individuals who meet any of the above three refugee criteria are able to enter Canada as part of the larger refugee class. The details of how refugees enter and locomote through the system are explained below. 6In March 2011, ClC published planned amendments to the Immigration and Refugee Protection Regulations, and it appears that the
entire Source Country Class is slated for elimination (ClC, 2011c). 


\section{THE STRUCTURE OF CANADA'S REFUGEE SYSTEM}

Canada accepts Convention refugees and Humanitarian-Protected Persons Abroad through two separate channels: the In-Canada Asylum program, and the Refugee and Humanitarian Resettlement Program (CIC, 2011e).

\section{IN-CANADA ASYLUM PROGRAM}

Under the In-Canada Asylum Program, individuals and families, called refugee claimants, or asylum claimants, independently travel to Canada and place refugee claims with an officer upon arrival at either a port of entry or an inland office (CIC, $2010 \mathrm{~g}$, s. 7.1). Placing an official asylum claim protects claimants from becoming subject to a removal until they undergo a refugee hearing before an Immigration and Refugee Board member. If the claimant's case is accepted and they are found to meet all eligibility and admissibility qualifications, then the secure status of 'protected-persons' is conferred to them.

If, on the other hand, a claimant's case is rejected at the Immigration and Refugee Board, they have a modicum of recourse through the application of a pre-removal risk assessment, by appealing the decision to the Federal court, or applying to the Minister of Citizenship and Immigration Canada to stay in the country based on humanitarian or compassionate grounds (CIC, 2007a). If claimants are similarly rejected through these alternate channels then they become subject to removal from Canada. Immigration through the In-Canada Asylum channel takes far more time and has greater elements of uncertainty in comparison with the following Refugee and Humanitarian Resettlement Program (Renaud, Piche, \& Godin, 2003, p. 89).

\section{REFUGEE AND HUMANITARIAN RESETTLEMENT PROGRAM}

Through this second stream, Refugee and Humanitarian Resettlement Program, people are ascertained to be refugees while they reside abroad, and therefore, do not undergo any determination process upon arrival to Canada. Refugees who arrive to Canada through this stream are automatically permanent residents? ${ }^{7}$ As the Admissibility and Transportation Loans

\footnotetext{
'The exception to this is when a refugee's resettlement is expedited as a case of "urgent need of protection" under the Urgent Protection Program (CIC, 2009a, s. 6.55). In these instances, people are usually en route to Canada within 3-5 days. If full admissibility and eligibility checks are not completed in time, then these persons are granted temporary resident permits and told to apply for permanent residency once all of the examinations are passed (s. 23.2).
} 
predominantly pertain to refugees coming through this channel, greater attention and detail will be paid here.

\section{Pre-Arrival: Eligibility and Admissibility of Applicants}

For refugees to be eligible for resettlement in Canada, they must be referred to the Canadian government by either the United Nations, another designated "referral organization", a private sponsor, or, in atypical instances, by self-referral (for example, in Source countries where there is no UN presence) (CIC, 2009a, s. 7; UN 2011c, Canada chapter). The majority of refugees selected for resettlement are referred by the United Nations (CIC, 2011b, p. 23). In addition to being referred, there are four conditions that must be met for an individual to be eligible for resettlement in Canada (CIC, 2010e, s. 7.18).

Firstly, as outlined above, they must meet the definition of either a Convention Refugee, or of the Humanitarian-Protected Persons Abroad (CIC, 2010e, s. 7.18). Secondly, the applicant's refugee claim must be deemed creditable. Thirdly, the applicant must not be better suited to either of the other two durable solutions: voluntary repatriation or local integration. Lastly, applicants must be able to demonstrate an ability to establish themselves in Canada. 'Ability to establish' is defined in government documents, as being able to provide for themselves and dependants, and to not rely on social assistance for food or shelter within three to five years after arrival (CIC, 2009a, s. 13.9).

After the appropriate referrals are made, interviews take place with immigration officers who assess the plausibility of the applicant's story, gather information not present in the paper file, and identify any special needs that the applicant may have (CIC, 2009a, s. 10.4). Concurrent to the interview, applicants also undergo the statutory requirements of medical, criminal, and security examinations $^{8}$ (CIC, 2010e, p. 7). Since the implementation of Canada's Immigration and Refugee Protection Act in 2002, applicants are no longer considered inadmissible if their medical conditions place an excessive demand on Canada's healthcare system ${ }^{9}$. And as to the criminal and security checks, applicants are considered unable to establish in Canada if they have committed any of the following: a crime against peace, a war crime, or a crime against humanity; a serious non-political crime; or been found guilty of acts that are contrary to the purpose and principles of the United

\footnotetext{
8 These processes are not always concurrent. In some offices abroad, a delay of two-to-three years may lapse between the initial interview and the completion of pre-departure medical exams (CIC, 2011b, p. 41).

${ }^{9}$ The medical exam will be discussed in more detail in the Admissibility Loan section.
} 
Nations (CIC, 2010e, s. 7.18). If all eligibility and admissibility criteria are satisfied then the officer approves resettlement for the applicant and any dependants ${ }^{10}$ (CIC, 2009a, s. 18.4).

\section{Post-Arrival: Three Sponsorship Types}

The Canadian government recognizes that newcomer refugees are unlikely to possess the resources and connections immediately upon arrival that are necessary for smooth integration into Canada. For this reason, there are established support structures in place to assist all resettled refugees during their first year in Canada. The three sponsorship programs are private, governmentassisted, and joint assistance.

\section{$\sim$ Private Sponsors}

In 1976, the Immigration Act first introduced private sponsorship as a way for Canadians to become involved in the resettlement of refugees (CIC, 2007b). This mechanism was fully exercised for the first time in 1979, as the exodus of "boat people" through Vietnam swelled to 290,000. The Canadian government responded to public pressure and raised entry quotas of Vietnamese -refugees from 5,000 in December 1978, to 12,000 in June 1978, and then to 50,000 by the end of 1980 (Kelley \& Trebilcock, 2000, p. 409). Additionally, the government also promised to match the entrance of one refugee for each privately sponsored refugee. Church groups and voluntary organizations took this pledge earnestly, and by 1981 some 77,000 South East Asia refugees had resettled into Canada (Knowles, 2007, p. 217)

The private sponsorship program has continued to grow and evolve, and in 2009, 2\%, or 5,036 of all the newcomers into Canada were privately sponsored (Refugee Sponsorship Training Program (RSTP), 2011, p. 3). One main feature of private sponsorships is that they are group endeavors. Corporations, unincorporated organizations and associations ${ }^{11}$, such as churches, mosques, ethnocultural organizations, and any "Groups of Five" Canadians, can apply to sponsor refugees from abroad (CIC, 2010e, s. 28). Agreements are signed, which confirm that the government will facilitate the refugee's arrival into Canada, and that the private sponsorship group will provide the in-Canada financial assistance, emotional care, and significant settlement supports for a period of

\footnotetext{
${ }^{10}$ If the principal applicant is found ineligible, then the eligibility and admissibility of the spouse, common-law partner, and any other dependants will be assessed. If one family member is found to qualify, then that status is applied to all other family members (CIC, 2009a, s. 13).

${ }^{11}$ Officially called Sponsorship Agreement Holders, Constituent Groups, Groups of Five, and Community Sponsors
} 
twelve months, or less if the refugees become self-supporting within that time (CIC, 2010e, s. 28; RSTP, 2011, p. 4). Private sponsorship groups can either identify specific refugees abroad that they wish to sponsor to come to Canada, or request that CIC match them with an individual or family on their behalf (RSTP, 2011, p. 4)

\section{$\sim$ Government-Assisted Sponsorships}

Government-assisted refugees (GAR) are fully supported by the government upon their arrival into Canada. Assistance is provided through the Resettlement Assistance Program (RAP), which is organized into the two components of income support and immediate essential services. Income support is provided for the first year in Canada, and this support may discontinue earlier, if a refugee becomes self-supporting within that timeframe (CIC, 2010e, s. 14.1). Service Providing Organizations (SPO) fulfill the second component, of administering essential and immediate services, on behalf of the government. Some of the services that SPOs provide include airport reception, provision of temporary accommodation, provision of a basic orientation to Canada, assistance in securing permanent accommodation, and referrals to other settlement programs, such as language learning (CIC, 2010e, s. 14.1).

\section{Joint Assisted Sponsorships}

This third type of support is a hybrid of the two sponsorships above, and is intended to provide a more comprehensive system of support for those identified as having higher integration needs. Some of the needs identified are individuals with physical or mental disabilities, atypical family types, such as single parents with multiple children, separated minors, and elderly persons (CIC, 2010 e, s. 48). As a way of providing fuller assistance, the government distributes financial assistance, usually for a period of 24 and up to 36 months, while the private sponsor is called upon to provide a considerable amount of time and effort to support the establishment of these higher need families and individuals. Refugees who are jointly sponsored, are able to access all of the immediate essential services like Government-assisted refugees, and can usually have their Immigration Loans paid for by a contribution from the RAP fund ${ }^{12}$ (CIC, 2010e, s. 8.4).

\footnotetext{
${ }^{12}$ The contribution fund will be fully discussed in section seven on financial details.
} 


\section{REFUGEES INTO CANADA}

In 2010, Canada granted permanent resident status to 280,681 people, which is the highest amount since 1957 when 282,164 people were admitted (Knowles, 2007, p. 274). Arrivals in 2010 represent almost 30,000 more than were accepted in 2009 (CIC, 2011a), and approximately 60,000 more than the average annual intake during the 1990s (CIC, 2010c). Of these 2010 permanent residents, the vast majority, 66.6\% (186,913), were economic migrants (CIC, 2011d). The remaining incomers came under the family class at $21.5 \%(60,220)$, as refugees at $8.8 \%(24,696)$, and under the "other" category at $3.1 \%(8,845)$.

Of the 24,696 who arrived under the refugee category in 2010 , the majority, 9,041 (36.6\%) were asylum claimants granted protected person's status (CIC, 2011d). The second largest contingent were Government-assisted refugees 7,264 (29.4\%), the third largest group were the $4,833(19.6 \%)$ privately sponsored refugees, and lastly were the 3,558 people (14.4\%), who arrived after primary applicant claimants, as dependants. The table below illustrates how, over the last five years, the number of government-assisted refugees have remained relatively constant between 7,200 and 7,600 , while the numbers of privately sponsored refugees have moderately increased overall, and the numbers of protected persons have dropped significantly.

Table 3.1: Refugees by Type into Canada, 2006-2010

\begin{tabular}{lcccccc}
\hline Refugee Type & $\mathbf{2 0 0 6}$ & $\mathbf{2 0 0 7}$ & $\mathbf{2 0 0 8}$ & $\mathbf{2 0 0 9}$ & $\mathbf{2 0 1 0}$ & $\mathbf{2 0 1 0 \%}$ \\
\hline Government-assisted & $\mathbf{7 , 3 2 6}$ & $\mathbf{7 , 5 7 2}$ & $\mathbf{7 , 2 9 5}$ & 7,425 & 7,264 & $\mathbf{2 9 . 4}$ \\
Privately Sponsored & $\mathbf{3 , 3 3 8}$ & 3,588 & 3,512 & 5,036 & 4,833 & $\mathbf{1 9 . 6}$ \\
Protected Persons & 15,884 & 11,696 & 6,994 & 7,206 & 9,041 & 36.6 \\
Dependants & 5,952 & 5,098 & 4,057 & $\mathbf{3 , 1 8 3}$ & 3,558 & $\mathbf{1 4 . 4}$ \\
\hline TOTAL & $\mathbf{3 4 , 5 0 6}$ & $\mathbf{2 9 , 9 6 1}$ & $\mathbf{2 3 , 8 6 6}$ & $\mathbf{2 4 , 8 5 9}$ & $\mathbf{2 6 , 7 0 6}$ & $\mathbf{1 0 0}$ \\
\hline
\end{tabular}

Note. From CIC, 2011d, Summary Tables-2006-2010

The most recent comprehensive statistics on refugee newcomers are derived from CIC's Facts and Figures 2009 report (2010). They show that of the 22,846 people under the refugee category in 2009, the majority, $47.4 \%(10,832)$, arrived from Africa and the Middle East (p. 23). Twenty-nine percent $(6,648)$ arrived from Asia and Pacific, $16 \%$ came from South and Central America, and the remaining $7.6 \%$ immigrated from the United States, Europe, and the United Kingdom. The two categories of 'Africa and the Middle East' and 'Asia and Pacific' have been the two largest source 
areas of refugees over the last ten years. These statistics also show that male and female refugee newcomers are nearly equal: in $2009,11,589$ males and 11,257 females arrived. 
The Immigrant Loans Program is a comprised of four separate loans: the Admissibility loan, the Assistance loan, the Right of Permanent Residence Fee loan, and the Transportation loan. Each of these loans were developed at different times, were created to address different and specific needs, and are available to different categories of applicants: they are outlined below.

\section{ADMISSIBILITY LOAN}

The objective of the Admissibility Loan is to offer financial assistance to Convention Refugees and members of the Humanitarian-Protected Persons Abroad Class to cover two main expenses. The first is the mandatory medical examination(s) that all potential refugees for resettlement must undergo. Prior to the Immigration and Refugee Protection Act (IRPA), the purpose of these medical checks was to assess each refugee's potential impact on Canada's health and social services, as well as to inform decisions on appropriate sponsorship type and resettlement location designations (CIC, 2009a, s. 14.1). After IRPA, Convention and Humanitarian-protected refugees became exempt from inadmissibility into Canada based on health grounds (IRPA, 2001, Section 38.1 and 38.2). Presently, refugees are permitted to resettle in Canada, even if it is determined that their medical conditions may place an excessive demand on health and/or social services.

The second purpose of the Admissibility Loan is to cover the cost of obtaining travel documents. The 1951 Refugee Convention, and the 1954 Convention Relating to the Status of Stateless People instated the right for refugees and stateless peoples to be issued Convention Travel Documents for the purpose of travel (UNHCR, 2011b, p. 134). As a signatory to the Convention Relating to the Status of Refugees in 1969, providing financial assistance under the Admissibility Loan for these documents is in keeping with Canada's international obligation.

According to CIC's Operation Procedure Manual on the Overseas Selection and Processing of Convention Refugees Abroad Class and Members of the Humanitarian-Protected Persons Abroad Class (2009a), there are three types of travel documents that can be obtained for one-way resettlement travel to Canada when official homeland documents cannot be obtained (CIC, 2010e). They are the International Committee of the Red Cross (ICRC) travel document, a UNHCR "Provisional Travel Certificate", or a Single Journey Document for Resettlement to Canada. Of note, the Citizenship and 
Immigration Canada website only references the ICRC and the Canadian issued travel documents as acceptable alternate documents (CIC, 2009b). This may be indicative of the infrequency in which the United Nations issues provisional travel documents.

\section{ASSISTANCE LOAN}

Unlike the Admissibility and Transportation Loans, which are only available to those applying to resettle in Canada from abroad, the Assistance Loan is also available to permanent residents and foreign nationals from within Canada (CIC, 2010e). The objective of the Assistance Loan is to alleviate some of the costs inherent with initial settlement in Canada (CIC, 2010f, s. 2.2). The Assistance Loan is lent in a single installment and endeavors to cover three cost areas: basic needs of life, basic household needs, and labour market access needs.

\section{BASIC NEEDS OF LIFE}

This loan is intended to help people establish themselves by attaining the essentials required for day-to-day living and human dignity. Anticipated initial costs include rent, utilities, food, clothing, and when warranted, incidental expenses, such as public transportation, personal hygiene items, non-prescription health-care aids and newspapers (CIC, 2010f, s. 11.2). In addition to the amount allotted for a single month's worth of the above, the basic needs of life category also include the initial residential set up costs of utility deposits (hydro, telephone, and gas), rental damage deposits, and/or a last month's rent.

\section{BASIC HOUSEHOLD NEEDS}

Financial assistance under this category is allotted for more tangible and long-term necessities, such as furniture (beds, window coverings, tables and chairs) and common household goods like kitchen utensils, cleaning supplies and bed linens (CIC, 2010f, s. 11.3).

\section{LABOUR MARKET ACCESS NEEDS}

This third type of assistance aims to address some of the barriers to employment that are more obvious and readily overcome; however, it should be mentioned that the operation manual states that this loan is only to be authorized in special circumstances (CIC, 2010f, s. 11.4). Under this 
rubric, monies are loaned for the purchase of apparel that particular jobs require (for example, a hard hat and steel-toed boots), for licensing examinations that are directly tied to employment offers, and for short-term childcare if a parent is required to begin working immediately. Two costs, which are explicitly stated as ineligible for loans are training courses, such as introductory computer courses intended to enhance a person's marketability, and medical treatments (CIC, 2010f, s. 11.4).

\section{RIGHT OF PERMANENT RESIDENCE FEE LOAN}

This loan is incongruent with the other three in loans under the Immigrant Loans Program because it is the only one that does not pertain to an immediate resettlement aspect. The Right of Permanent Residence Fee loan is available to foreign nationals and permanent residents who are applying for permanent residence for themselves and/or their dependants (CIC, 2010f, s. 6.13).

On February 28, 1995 the Federal Budget instituted a \$975 Right of Landing Fee (ROLF) upon all those applying to become permanent residents in Canada (CIC, 2008, s. 7.26). Implementation of this fee was justified by arguments that the generated funds would both contribute towards defraying costs associated with the delivery of immigration programs, and also partially compensate for the benefits that the individual had already utilized before acquiring permanent resident status. At the time of ROLF's implementation, the government created this particular federal loan to help refugees and immigrants cover the new fee (CIC, 2008, s. 7.26).

There have been three major changes since this fee was implemented in 1995. To begin, in 2000, all Convention Refugees and members of the Humanitarian-Protected Persons Abroad Class were officially exempted from having to pay a fee to become permanent residents [CIC, 2008, s. 7.26; CIC, 2010f, s. 12.1). A second smaller change came in 2002 when IRPA changed the name from ROLF to the Right to Permanent Residence Fee. And lastly, in 2006, the Federal Budget reduced the Right of Permanent Resident Fee from $\$ 975$ to $\$ 490$ (CIC, 2008, s. 7.26). At the time of ROLF's implementation in 1995, refugees were the primary users of the ROLF loan (CIC, 2008, s. 7.26). Since their exemption from the fee in 2000 , the demand for this loan has decreased dramatically (CIC, 2008, s. 7.26). 


\section{TRANSPORTATION LOAN}

The Transportation Loan's objective is quite simple. It provides financial assistance to foreign nationals, Convention Refugees, and members of the Humanitarian-Protected Persons Abroad Classes and their dependants to cover costs incurred in the journey to Canada (CIC, 2010f, s. 2.4). The Transportation Loan potentially covers four main expenses. The first is transportation from a rural community or camp-based place of residence to a city where air travel to Canada can commence (CIC, 2010f, s. 13.2). The second cost is the mandatory International Organization of Migration service fee. The third expense is the airfare to Canada by the most economical and direct route. The final expense is in-Canada transportation costs, such as overnight accommodation, meals, and ground transportation. In the case of unexpected overnight stays, Government-assisted refugees will have the accommodation costs covered by a contribution payment from the Resettlement Assistance Program (RAP) (CIC, 2009a, s. 3.1). In contrast, privately sponsored refugees have these accommodation and related costs added to their Transportation Loan total (s. 3.3).

\section{THE INTERNATIONAL ORGANIZATION OF MIGRATION}

The International Organization of Migration (IOM) was established in 1951 as an intergovernmental organization to manage the migration of refugees after World War II (CIC, 2005b; 1OM, 2011b). Today the IOM continues its mandate to uphold orderly and humane migration, while additionally promoting international cooperation and problem solving among its 132 member nation states (IOM, 2011b).

In addition to its intergovernmental objectives, the IOM also provides many practical services on behalf of Canada and other resettlement countries. Canada contracts the IOM to not only provide orientation sessions on adapting to life in Canada, but to also undertake the enormous task of coordinating the pre-departure medical exams and transportation logistics for all Canada-destined refugees. The IOM charges a fee for these services, which is passed on to the refugee to repay. According to the Immigration Loans Program's operation manual, as of 1998, the fee was USD $\$ 100 / C D N \$ 148$ per person with a maximum of USD $\$ 400 / C D N \$ 592$ per family (s. 16.2). All requests to the $10 \mathrm{M}$ for a more recent per person figure were unanswered. 
One significant benefit to using the IOM's services lie in their economy of scale, which enable them to provide significantly reduced airfares, called "concession fares" (IOM, 2011a). A 2005 CIC evaluative report on Canada's membership in the IOM found that there were moderate to considerable savings on airfare prices. Two of the most significant discounts were from Accra, Ghana and Nairobi, Kenya to Toronto. The IOM's prices were only $47 \%$ of otherwise regular advance-purchase airfare prices ( $\mathrm{CIC}, 2005 \mathrm{~b}$ ). Of the eighteen originations detailed, the average $10 \mathrm{M}$ ticket price was $62.6 \%$ of the regular ticket price; or, said alternately, in 2005 , the IOM offered an average savings of $37.4 \%$ on airfare costs.

Table 4.1: Comparison of IOM and Regular Price Airfares to Toronto in 2005

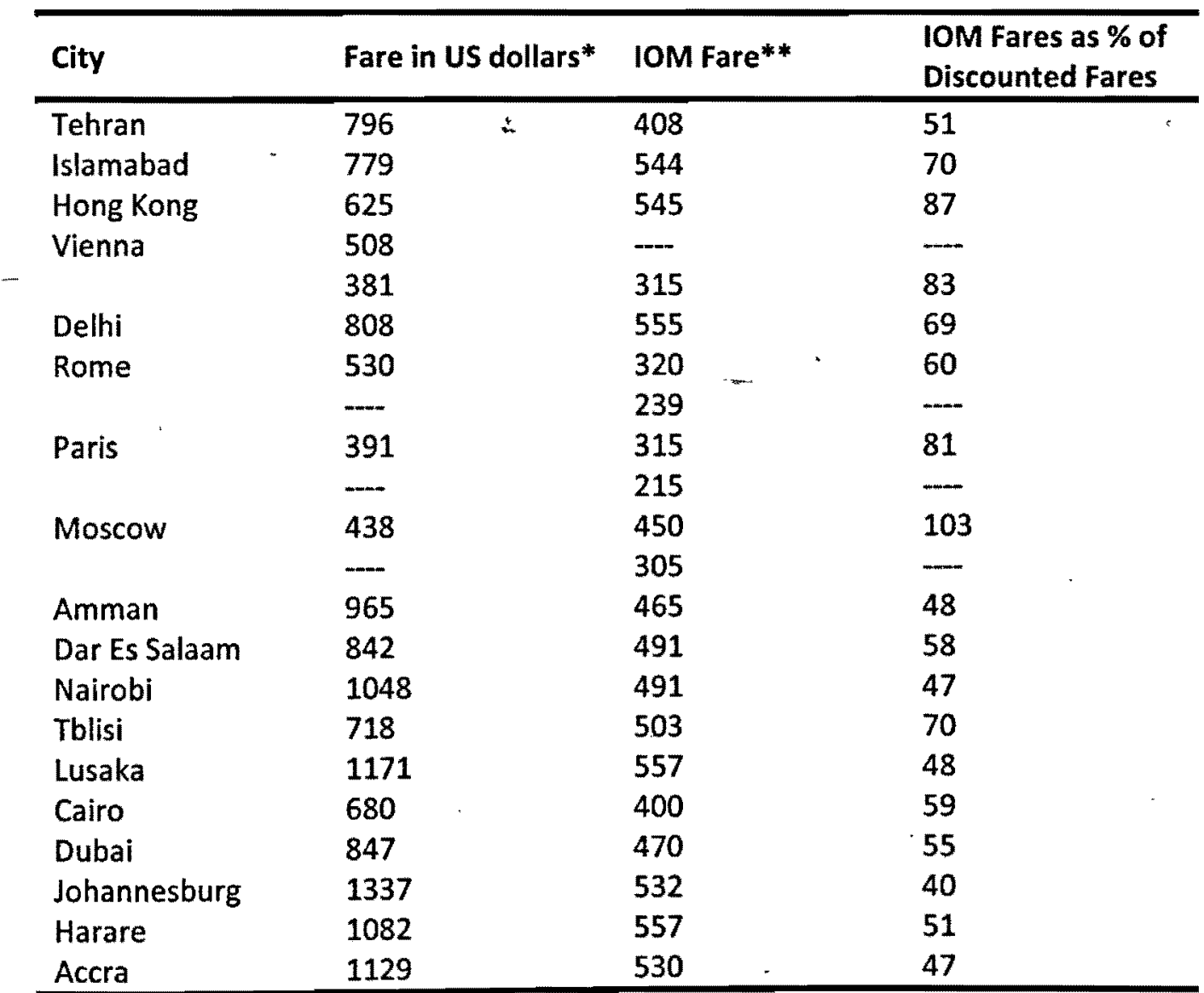

Note. From CIC, 2005, Report on the evaluation of Canada's membership in the International Organization for Migration.

* The fare used equals one-half the adult fare, based on an advanced purchase discounted fare.

** Where two fares are listed, they refer to the adult and children's fares, respectively 
According to IOM officials, of the world's twenty-two resettlement countries, Canada stands alone in recovering from refugees the combined costs of medical exams, travel documents, airfare, and travel related costs. Canada is also the only nation to charge refugees interest on these loans (CIC, 2011b, p. 40; UN, 2011a). Interesting comparisons can be made from analyzing the various country chapters included in the 2011 United Nations Resettlement Handbook.

Many resettlement countries have included a chapter detailing its resettlement processes, and it is quite clear that there exists no established international protocol on how to resettle refugees. For example, not all national governments undertake payment of the transportation costs by themselves. In Benin and Chile, the transportation costs are borne by either the UNHCR, or by the in-country party that is sponsoring the refugee's resettlement (UNHCR, 2011c, Benin, p. 5, Chile, p. 4). A cross-national comparison also shows that many countries, like Canada, admit refugees regardless of high medical needs and costs, and that there is a significant variance in medical assessment procedures. For example, Iceland does not to conduct precursory medical examinations abroad like Canada, but instead examines incoming refugees after their arrival (UNHCR, 2011c, Iceland, p. 3). They believe that this order of process best identifies settlement and resource needs.

Britain is only other country that charges resettling refugees for medical exams; however, the terms are markedly different from Canada, and this seldom, if ever, occurs. In essence, Britain does not accept people with high medical needs for resettlement (UNHCR, 2011c, Great Britain, p. 9), while Canada does. In the case of Canada, all potential refugees for resettlement must undergo and bear the costs of IOM administered standard medical exam(s). In contrast, Britain covers the cost of all its potential refugees to undergo the less rigorous process of IOM medical screening. This process is used to separate out those who are ineligible for resettlement based on their medical conditions.

The only instance in which individuals resettling to Britain would pay for the cost of a medical exam, is if they successfully pass through the mandatory and paid-for IOM medical screening, but have their health conditions reconsidered by one of Britain's Entrance Clearance Officers (UNHCR, 2011c, Great Britain, p. 9). If an Entrance Clearance Officer suspects an undetected medical 
condition, they have the discretion to submit the applicant for an additional medical exam. If this occurs, the individual is then responsible to bear the exam's cost.

In actuality, Britain only accepts around 500 refugees for resettlement per year (UNHCR, 2011c, Great Britain, p. 1), and it is unlikely that many, if any, applicants have to undergo an additional medical exam. A likely reason for this is that the extremely high competition would result in the forwarding of only the very 'strongest' applicants. There is no mention of how refugees would be expected to pay for this exam.

As to transportation costs, the United States is the only other country to recoup these expenses from refugees. There are four basic differences between the ways that Canada and the US administer their loans. Chiefly, the United States does not charge interest on their loan. Secondly, Canadian refugees make repayments directly to the government, while American refugees repay the IOM, or its associated local settlement agencies (IOM, 2010). Thirdly, refugees in the US have six months until their loan repayment period commences, compared to thirty days in Canada (UNHCR, 2011c, United States, p. 9). And lastly, regardless of the loan size, refugees in the US are given three and one-half years to repay the balance. In contrast, Canadian loans are repaid within one to six years, depending on the amount, and are subject to interest after the first to third year (IRPR, 2002, s. 293.a.b.c). Although the differences between the two loan terms appear relatively minor at first glance, they become enlarged when the sizes of the loan are compared: Canadian resettling refugees are repaying up to three loans while those in the US are only covering transportation costs. 
One consequence of the Immigration Loan's multifaceted nature is that it tends to confuse and frustrate earnest discussion about its impacts. In addition to miscommunication stemming from the previously mentioned tension between paternalistic and empowerment perspectives, the discourse is further muddled by the frequent conflation of the Admissibility and Transportation Loans. As well, misunderstanding is generated by the variety of impacts that the loans have on different groups of people. The following section seeks to highlight and clarify these two fundamental nodes of confusion.

\section{CONFLATION OF ADMISSIBILITY AND TRANSPORTATION LOANS}

Refugee advocates are clear in their calls to end the Transportation Loans; however their directives regarding the Admissibility Loan are less explicit. More often than not, the costs of medical exams and travel costs are simply blended together under the single banner of the Transportation Loan. To demonstrate, the Canadian Council for Refugees (CCR), a prominent and reputable refugee advocacy organization, has taken up abolition of the Admissibility and Transportation Loans as one of its six steadfast signature campaigns. The CCR's quest to "End the burden of refugee Transportation Loans" describes the issue on its website as follows: "Refugees resettled to Canada must pay for their medical exam and their travel to Canada" (italics added, CCR, 2011b). Refugee advocates are not alone in this conflation. Citizenship and Immigration Canada's Evaluation of Government-assisted Refugee (GAR) and Resettlement Assistance Program (RAP) (2011b) similarly conflated the Admissibility and Transportation Loans by stating, "The travel loan is approved to cover the costs of medical examinations abroad, travel documents, and transportation to Canada" (p. 60).

The conflation of these two loans results from a number of different reasons. One fundamental factor is that there does not exist an online or electronic mechanism to separately track transportation and medical costs (CIC, 2011b, p. 8). When interviewed, IOM staff highlighted Canada's paper based system and practice of using actual figures as problematic and inefficient in comparison to the American system, which uses both digital files and cost estimates (CIC, 2011b, p. 40). As the Canadian system presently stands, conflation of the two loans is the natural result: the separation of admissibility and transportation related costs are neither readily accessible nor easily calculated. 
A second reason for amalgamating the two loans is because doing so makes it easier to debate and explain. For example, not only can an argument against the "Admissibility and Transportation Loans" sound cumbersome, but the ambiguity surrounding the meaning and terms of 'admissibility' may also serve to detract from the argument's vigour. This relates to a third factor that the high cost of airfare suggests that the Transportation Loan comprises the much larger share of the two loans; as such, introduction of the more inconsequential admissibility cost may detract from and weaken the more impactful argument of the Transportation Loan. A final factor, which influences the conflation of the two loans, stems from the fact that the loan is capped at $\$ 10,000$. In the instances of large families, where expenses exceed $\$ 10,000$, who can determine if it is the admissibility or transportation costs that are forgiven above the capped amount? If this last factor is indeed traceable, there is currently no identified public account of how this is calculated.

\section{THE VARIOUS IMPACTS OF THE IMMÏGRATION LOANS: NARROWING DOWN THE ANALYSIS}

There are five groups of people who are eligible for various combinations of loans under the Immigration Loans Program: Canadian citizens, permanent residents, foreign nationals, Convention Refugees, and members of the Humanitarian-Protected Persons Abroad Class. According to the Immigration and Refugee Protection Regulations (2001), the first three groups listed, Canadian citizens, permanent residents, and foreign nationals, are each able to apply for loans to help defray the costs associated with their dependents'/beneficiaries' transportation, medical exams and administration, as well as with the permanent resident fees.

In practice, although the Admissibility and Transportation Loans are available to these three groups, it is understood that virtually none apply for them. This is due to that fact that family sponsors must demonstrate financially viability: requiring a loan for travel and admissibility costs would contravene this principle. Under the Immigration Loans Program, these three groups primarily use the Permanent Resident Fee Loan, but again, in actuality these groups represent a small fraction of those approved for the Immigration Loan (CIC, 2010f, s. 5.1)

In contrast, Convention Refugees and members of the Humanitarian-Protected Persons Abroad Class have no need to take out Right of Permanent Residence Fee loans, as they have been exempted from paying this fee since 2000 (ClC, 2010f, s. 12.1). These two designations of refugees also have only minimal use for the Assistance Loan because the financial assistance provided by the 
government and private sponsors accounts for the majority of start-up costs. To illustrate, in the case of GARs and JAS refugees, the start-up cheque provided by the government includes a nonrepayable basic household needs allowance, which is intended to cover the very same initial costs outlined in the Assistance Loan fund: furniture, cleaning supplies, bed linens, etc. (CIC, 2010e, s. 15.5). Moreover, GARs and JAS are also provided with an allowance for utility installation and clothing. As such, GARs and JAS refugees only tend to use an Assistance Loan for a rental/damage deposit (CIC, 2010d, p. 13).

Like GARs and JAS refugees, privately sponsored refugees are similarly provided with many of the basic provisions required to set-up a life in Canada. The Refugee Sponsorship Training Program (RSTP) advises potential private sponsors to not only budget for monthly costs, but to also factor in onetime start-up expenses such as: "clothing, furniture, household effects like bedding, school startup costs, and utility hook-up fees" (RSTP, 2011, p. 81).

It is important to understand that after a person is accepted for resettlement, the distinction of being a Convention Refugee or member of the Humanitarian-Protected Persons Abroad Class becomes irrelevant. The factor that determines an individual or families' relationship with the loans is dependant upon whether they arrived under the auspices of a joint assistance, private, or government sponsorship. Said otherwise, the loans affect refugees differently depending upon the sponsorship agreement that they are under for the first twelve months.

\section{A NOTE ON USE OF THE TERM 'REFUGEE'}

An important point should be discussed on the usage of the term 'refugee' within this paper. Hyndman (2009) reminds researchers about the importance of acknowledging and discussing the power relations associated with refugee resettlement in order to not reproduce the associated social, economic, and political hierarchies (p. 248). Being mindful of this, this paper recognizes that it is problematic to label a person a 'refugee' when they are, in fact, citizens and permanent residents. When the label "refugee" is applied to a person who has resided in Canada for a number of years, the word comes to be construed as a "powerful act of subjugation", and one that implies a status of 'outsider', in contrast to membership or belonging (p. 249). This paper appreciates that people seldom self-identify as refugees after receiving permanent status (Hyndman, 2009, p. 248) and does not use the term in such a manner. 
The term 'refugee' is necessarily used within this paper to distinguish between the distinctly different resettlement experiences of the economic, family, and refugee classes in Canada within the short term. The label is also used to discuss the various bureaucratic categorizations of Government-Assisted, privately sponsored, and Joint Assisted Sponsored refugees. This use of the term in this regard is precisely what Roger Zetter (2007) describes as the transformation and "fractioning" of the label 'refugee' (p. 172). He cautions his readers to be conscious of the tendency of labels to overly simplify meanings and reinforce arbitrary discrimination. He also notes that in today's environment, the 'refugee' label is manipulated and managed by governments, rather than NGOs, and that it is a process primarily motivated by the interests of the 'global north' (p. 176). The word 'refugee' in this paper does not intend to reproduce unequal power structures, but rather, is conscionably used to distinguish and discuss the different degrees and locations of opportunity and power.

\section{THE LOANS AFFECT REFUGEES DIFFERENTLY DEPENDING ON THEIR SPONSORSHIP ARRANGEMENT}

\section{Joint Assistance Sponsorship (JAS)}

Those who arrive under Joint-Assistance sponsorship arrangements are customarily determined to be special-need cases before their arrival into Canada. Circumstances identified as requiring highresettlement needs include very large families, trauma resulting from violence or torture, medical disabilities, and systemic discrimination (RSTP, 2011, p. 119). At the same time that visa officers designate individuals and families as JAS, they also officially recommend that these particular individuals and families have their admissibility and transportation costs covered by a contribution from the Resettlement Assistance Program (RAP) (CIC, 2010e, s. 8.4).

Each year, the Refugee Resettlement Division of CIC budgets a different amount for this purpose. In 1999 , the budget was $\$ 400,000$, in $2007-2008$ it was only $\$ 109,126$, and in $2008-2009$, it was back up to $\$ 339,611$ (CIC, 2011b, p. 61). The Refugee Resettlement Division estimates that the contribution fund can potentially assist between forty and fifty families per year. The repayment experiences of JAS refugees have not been identified in the academic, policy, or advocacy literature; it can, therefore, be reasonably presumed that the majority of these individuals and families are granted contributions, and not charged with repaying their Admissibility and Transportation Loans. 


\section{Privately Sponsored Refugees (PSR)}

Individuals and families that arrive into private sponsorship arrangements may or may not have their Admissibility and Transportation Loans paid for by their sponsors. It is unclear exactly what percentages of privately sponsored refugees have these costs taken care of by their sponsors. There are, however, clearly established routes that can be taken if private sponsors wish to help those they are sponsoring by either paying off a lump-sum, the entire balance, or contributing monthly payments (CIC, 2010f, s. 9.2-9.5). Some organizations such as the Canadian Unitarian Council dissuade sponsors from paying off this loan for refugees, fearing that the loan may be discontinued to privately sponsored refugees, which would then leave sponsors on the hook for these costs (Canadian Unitarian Council, 2005, p. 14). Similar to JAS refugees, PSRs are virtually unmentioned in the discourse of Admissibility and Transportation Loan repayment.

\section{Government-Assisted Refugees (GAR)}

Government-assisted refugees, unlike JAS and privately sponsored refugees, are independently and wholly responsible for the repayment of their Admissibility and Transportation Loans. JAS refugees appear to have these costs covered by the contribution fund, and privately sponsored refugees are often actively and/or latently assisted with the financial repayments. Therefore, by a process of elimination that separates groups who are not absolutely affected by these two loans, GARs are the single remaining group. There is scant literature on the Immigration Loans, and the majority of what is written pertains specifically to GAR's experiences repaying the Transportation Loans. It is for this reason that GAR figures are the most heavily cited in the remainder of the paper. 


\section{SECTION 7: THE IMMIGRATION LOAN'S FINANCIAL DETAILS}

The loans program, which began in 1950 as the Assisted Loans Passage fund with a $\$ 9$ million budget, has grown to encompass four loans with the much larger budget of $\$ 110$ million. Today the Financial Branch of CIC is responsible for administration of the Immigration Loans Program (CIC, 2005a). This section explains the conditions under which loans are written-off, as well as the terms of repayment, the average Transportation Loan size for Government-assisted refugees, interest, deferral, and contributions payments. Before these are discussed; however, it would be useful to have an understanding of the Consolidated Revenue Fund and the Immigration Loans Program's scope.

The Consolidated Revenue Fund is the pool into which all federal revenue is placed and managed (Public Works and Government Service ${ }_{2}$ Canada, 2010). In addition to the Immigration Loan repayments, all federal revenues collected from taxes, tariffs, license fees, and Crown corporation profits are also put into this fund. The Consolidated Revenue fund is used to make federal payments such as the Canadian Pension Plan, Old Age Security, and the Child Tax Benefit. To get a sense of the budget, in the 2009-2010 fiscal year (ending March 31 ${ }^{\text {st }}$ ), the total revenues received by the federal government were $\$ 218.6$ billion, and of these revenues, over $\$ 34.65$ billion were paid out in Old Age Security benefits, guaranteed income supplements, and spousal allowances (Government of Canada (GOC), 2010, Tbl. 1).

In regard to the Immigration Loans Program, of the budgeted $\$ 110$ million, there is currently (2010) $\$ 76,345,908$ available in the fund (GOC, 2010, s. 6.4). Said otherwise, of the $\$ 110$ million available to the Immigration Loans fund, $\$ 33.65$ million has been lent out in total. In the last fiscal year of 2009-2010, \$4.33 million was distributed in Immigration Loans, $\$ 1.2$ million was paid to the IOM, and $\$ 828,006$ in loans was written-off (GOC, 2010, s. 6.4). Interestingly, this last year has proven exceptional, for it is the only year of the past ten where more money was given out of the Immigration Loans fund than was received.

For the previous nine years of 2001 to 2009 , the government actually received more money in "receipts and other charges" than it lent out in "payments and other charges" (GOC, 2010, p. 256). The table below was created using the CIC figures within the Public Accounts volumes I \& II from the years 2001-2010. The figures show that the amounts lent out have varied widely over the 
years. For example, the government profited at the high end with $\$ 4.13$ million in 2001 , at the low end in 2005 with $\$ 551,306$, and in 2010 spent $\$ 4.33$ million more than it took in.

Table 7.1: Financial Overview of Immigration Loans Program

\begin{tabular}{|c|c|c|c|c|c|c|c|}
\hline Year & $\begin{array}{l}\text { Total Lent } \\
\text { from } \$ 110 \\
\text { million fund }\end{array}$ & $\begin{array}{l}\text { Annual } \\
\text { Amount Lent } \\
\text { Out }\end{array}$ & $\begin{array}{l}\text { Annual } \\
\text { Amount } \\
\text { Paid to } \\
\text { IOM }\end{array}$ & $\begin{array}{l}\text { Annual } \\
\text { Repayment } \\
\text { Amounts }\end{array}$ & $\begin{array}{l}\text { Revenue } \\
\text { from Loan } \\
\text { Interest* }\end{array}$ & $\begin{array}{l}\text { Number of } \\
\text { Loans } \\
\text { Written-off }\end{array}$ & $\begin{array}{l}\text { Total } \\
\text { Amount } \\
\text { Written-off }\end{array}$ \\
\hline 2010 & $33,654,092$ & $4,334,386$ & $1,201,171$ & $13,314,633$ & 543,081 & $3,013^{* *}$ & $828,006^{* *}$ \\
\hline 2009 & $34,389,807$ & $(735,718)$ & $1,356,248$ & $11,752,872$ & 559,693 & $n / a * * *$ & $n / a^{* * *}$ \\
\hline 2008 & $38,080,244$ & $(3,690,436)$ & $1,109,300$ & $14,927,695$ & 663,017 & 2,813 & $1,620,031$ \\
\hline 2007 & $40,271,171$ & $(2,190,925)$ & $1,074,870$ & $14,440,032$ & 734,207 & 3,164 & 986,871 \\
\hline 2006 & $41,942,973$ & $(1,671,802)$ & $1,012,552$ & $15,245,408$ & 798,697 & 3,583 & 978,102 \\
\hline 2005 & $42,494,279$ & $(551,306)$ & $1,204,557$ & $13,757,773$ & 892,540 & 2,561 & 920,210 \\
\hline 2004 & $43,525,673$ & $(1,031,394)$ & $1,120,118$ & * $14,919,380$ & 898,486 & 2,376 & 777,911 \\
\hline 2003 & $47,218,406$ & $(3,692,773)$ & $1,150,850$ & $12,218,705$ & 875,958 & 2,659 & 664,273 \\
\hline 2002 & $50,940,489$ & $(3,722,083)$ & $1,010,142$ & $16,958,705$ & 949,113 & 3,394 & $1,757,203$ \\
\hline 2001 & $62,102,956$ & $(4,126,939)$ & $1,126,860$ & $18,031,770$ & 909,961 & 3,217 & 706,641 \\
\hline
\end{tabular}




\section{WRITE-OFFS}

There are a number of conditions that must be exhausted before a debt to the Canadian gavernment can be written-off. The three most relevant to Immigration Loan holders are a current incapability to repay the debt; incapacity to repay the debt in the foreseeable future; and the nonpossession of financial assets or properties that can be applied towards the debt (Department of Justice, 1994). Each year the federal government writes-off around two to three thousand loans; unfortunately for researchers, the details of which loans are deferred and for what reasons are not publically available.

There are two points to note from the Public Accounts in regards to Immigration Loan write-offs. The first is the changed wording that occurred between the 2008 and 2010 reports. In 2008 the Public Accounts broadly worded the write-offs as, "...debts due to Her Majesty in right of Canada amounting to $\$ . . . . "$ In 2010 , text was added to explicitly state that the amounts written-off were "related to immigration loans issued pursuant to Section 88 of the Immigration and Refuge Protection Act." The second point of observation is that write-offs are not at all mentioned in the 2009 Public Accounts. This omission may have been the result of having the write-off function curtailed in the wake of the economic recession.

\section{IMMIGRATION LOAN REPAYMENT SCHEDULE}

It is challenging to make broad statements about Immigration Loan repayments because each loan's terms vary according to the amount, and from where the loan is made. In reference to the latter, if the loan holder is arriving from abroad, then repayment commences thirty days after they arrive into Canada (Immigration and Refugee Protection Regulations [IRPR], 2001, s. 291). Alternately, if the loan is procured within Canada, for example, permanent residents undertaking Right of Permanent Resident Fee loans for their dependents, then the repayment period begins thirty days from when the loan is made.

The repayment schedule also varies according to the loan's total. Loan holders are given up to 12 months for loans under $\$ 1,200$; up to 24 months for loans between $\$ 1,200$ and $\$ 2,400$; 36 months for loans between $\$ 2,400$ and $\$ 3,600 ; 48$ months for loans between $\$ 3,600$ and $\$ 4,800$; and 72 months if the loan is greater than $\$ 4,800$ (IRPR, 2001, s. 291.2.a-e). If loan holders miss loan 
payments, or their payments are insufficient CIC may refer the accounts to private collection agencies (CIC, 2010f, s. 15.4).

Table 7.2: Immigration Loan Repayment Schedule

\begin{tabular}{lc}
\hline Loan Total & Payment Period \\
\hline Less than $\$ 1,200$ & 12 months \\
Between $\$ 1,200-\$ 2,400$ & 24 months \\
Between $\$ 2,400-\$ 3,600$ & 36 months \\
Between $\$ 3,600-\$ 4,800$ & 48 months \\
Over $\$ 4,800$ & 72 months \\
\hline
\end{tabular}

Note. From Immigration and Refugee Protection Regulations, 2001, s.291

\section{TRANSPORTATION LOAN AVERAGES FOR GARS}

The average Transportation Loan amount per single Government-assisted refugee over the five years of 2005 to 2009 was $\$ 2,821$. As seen in the table below, the loan amount per person decreased as the family size increased (CIC, 2011b, p. 61). The figures in this table reflect Transportation Loans alone; in addition to these totals, the admissibility costs of medical exams and travel documents would be added, as would an Assistance Loan covering a first month's rent or damage deposit.

Table 7.3: Average Loan by Family Size for GARs Admitted to Canada, 2005-2009

\begin{tabular}{cccc}
\hline $\begin{array}{c}\text { Number of People in } \\
\text { Case }\end{array}$ & Percentage of Cases & Mean Loan Amount & $\begin{array}{c}\text { Loan Amount Per } \\
\text { Person }\end{array}$ \\
\hline One & $25 \%$ & $\$ 2,845$ & $\$ 2,845$ \\
Two & $27 \%$ & $\$ 3,694$ & $\$ 1,847$ \\
Three & $22 \%$ & $\$ 5,150$ & $\$ 1,717$ \\
Four & $12 \%$ & $\$ 6,008$ & $\$ 1,502$ \\
Five & $7 \%$ & $\$ 7,195$ & $\$ 1,439$ \\
Six & $4 \%$ & $\$ 6,959$ & $\$ 1,160$ \\
Seven & $2 \%$ & $\$ 7,277$ & $\$ 1,040$ \\
Eight & $1 \%$ & $\$ 6,217$ & $\$ 777$ \\
Nine & Less than 1\% & $\$ 9,030$ & $\$ 1,003$ \\
\hline
\end{tabular}

Note. From Loans Database, published in $\mathrm{ClC}, 2011 \mathrm{~b}$, Evaluation of Government-assisted refugees and resettlement assistant program, p. 61 


\section{INTEREST}

The interest rate applied to Immigration Loans is identical to the rate set by the Minister of Finance for Crown corporation loans in January of each year (CIC, 2005a). Loans are assigned the interest rate of the year in which they are made, and remain fixed for the duration of the loan's repayment. If a loan holder takes out a subsequent loan while still repaying an earlier one, then the interest rate from the first loan will be retained for the second loan (IRPR, 2001, s. 293.6). Interest is calculated daily, and compounded monthly [s. 293.5).

The six-year repayment schedule is out of step with the interest schedule, for all unpaid loan amounts over $\$ 2,400$ begin accruing interest after the end of the third year, regardless of whether they have four, five, or six years to repay the total. Specifically, loans under $\$ 1,200$ that are not repaid in full within one year will begin to have interest accrue on the first day of the thirteenth month. Similarly, loans between $\$ 1,200$ and $\$ 2,400$ that are not fully repaid within two years will have interest applied on the first day of the twenty-fifth month. All loans with an outstanding balance over $\$ 2,400$ at the end of the thirty-sixth month will begin to have interest applied at the beginning of the thirty-seventh month.

Table 7.4: Interest Schedule for Immigration Loans

\begin{tabular}{lc}
\hline $\begin{array}{l}\text { Remaining Balance After } \\
\text { Repayment Period Ends }\end{array}$ & Interest Begins in this Month \\
\hline Less than $\$ 1,200$ & 13 \\
Between $\$ 1,200-\$ 2,400$ & 25 \\
Between $\$ 2,400-\$ 3,600$ & 37 \\
Between $\$ 3,600-\$ 4,800$ & 37 \\
Over $\$ 4,800$ & 37 \\
\hline
\end{tabular}

Immigration and Refugee Protection Regulations, 2001, s.291

Note. From

Over the last ten years, the federal government has collected over 7.8 million dollars in interest on the Transportation and Assistance Loans (GOC, 2001-2010). There are two interesting observations to note: firstly, the amounts collected in interest are decreasing each year. The most interest collected in a single year was $\$ 949,113$ in 2002 , and the amount has steadily lessened down to the $\$ 543,081$ collected in 2010 . This is likely due to the lesser amounts being used by the Immigration Loans Program each year and to the shifting interest rates. In 2001 the government was using $\$ 62.1$ million of the $\$ 110$ million available; ten years later the amount of the fund used 
has almost halved to $\$ 33.65$ million. A second interesting point is that the Public Account tables clearly state that the interest collected is from the Transportation and Assistance Loans. This presumably signals that these two loans comprise the largest proportion of the Immigration Loans.

\section{DEFERRAL}

Many of the government's websites and publications point out that if people are experiencing financial hardships in repaying their Immigration Loans, they are able to apply for a variety of easements (i.e. CIC, 2010 d, p. 14). To explain, loan holders can apply to have the commencement of their repayment period delayed, to have their payments delayed after the repayment has begun, to adjust the payment amounts, or to have the repayment period extended (IRPR, 2001, s. 292.2). In the case of resettling refugees, the repayment period cannot be extended beyond an additional twenty-four months, and it cannot be extended more than six months for other loan holders. Comprehensive details about the numbers of deferrals requested are unavailable; however, it was recently published that of all the GARs who entered Canada between 2005-2009, only $1 \%$ of those had procured loans deferrals (CIC, 2011b, p. 62).

This low deferral rate is likely the result of three factors. The first and most obvious is that many people do not require a deferral. Of the above-mentioned 2005-2009 GAR cohorts, 56\% were either in the process of paying off or had fully repaid their Transportation Loans. A second reason for the low deferral rate may stem from the bureaucratic challenges of obtaining one. The process could be perceived as somewhat daunting by a GAR newcomer, for they must first approach a local immigration office, which will designate an officer to them, and the officer will then refer the loan holder's situation to Collection Services in Ottawa (CIC, 2010f, s. 14.4)

The third, and perhaps most compelling point regarding deferrals is that anyone who changes the terms of their loan is almost certainly unable to sponsor family members. This information is most clearly outlaid in the private sponsorship handbook, which explicitly states that applications to sponsor family members will be seriously compromised if they are considered to be in arrears. Arrears, in these instances, are defined as paying less than the full amount assigned by the government, even if it has been approved as a deferral (p.90). 
The official Immigration Loans Program's operation manual is less forthcoming with specifics and states,

These persons will need to satisfy the designated officer reviewing the family-class sponsorship request that they have not defaulted on their loan payments in order to demonstrate their ability to support family dependants (italics added, s. 14.4).

A phone query to CIC's Collection Services highlighted that the emphasis of the above statement is as much upon the "ability to provide support" as it is upon meeting the condition of 'not defaulting.' Fundamentally, the government interprets any alteration to the payment schedule as evidence of an inability to support dependants.

\section{CONTRIBUTIONS}

In February of 1997, the Canadian government created the stipulation that special-needs refugees selected from abroad, such as single parents, large families, women at risk, the elderly, and those disabled, are eligible to have their admissibility and transportation costs paid for on their behalf by a contribution from the budget set aside from the Resettlement Assistance Program (RAP) (CIC, 2010f, s. 8.1; CIC, 2010e, s. 7.10). According to the RAP's terms and conditions, it is also possible to convert Assistance and Transportation Loans into RAP contributions after arrival in Canada; however, in reality this seldom occurs.

This appears to be primarily due to three reasons. Firstly, knowledge of this mechanism is little known and under utilized among Canadian Based Officers (CIC, 2011b, p. 61). Secondly, JAS cases are prioritized, and GAR conversions are stressed as to only occur under exceptional circumstances (CIC, 2010f, s. 11.8). Lastly, the economic recession has resulted in a retractive climate that has essentially suspended the allocation of contribution funds to convert in-Canada GAR Admissibility and Transportation Loans (personal communication, July 21, 2011). 
Up to this point, the paper has striven to give the reader a strong foundation based in facts. In this final analytical section, the benefits of repaying the loans will be assessed, as will some costs through a framework of refugee advocate's concerns. Lastly, a few comments will be made regarding the future of the Admissibility and Transportation Loans.

To reacquaint with the paper's opening ethos of holism, a paternalistic discourse focuses on a refugee's needs, while the empowerment dialogue emphasizes a refugee's self-reliance capabilities. Independently, neither of these perspectives yields an authoritative view of the loans; however, they are revealing when considered together. An additional point to be made at this juncture is that a dearth of data that disaggregates refugee types, in conjunction with the complex nature of analyzing migration issues has somewhat inhibited the production of a deeper and more detailed analysis. As such, the following arguments are presented to the reader for consideration with an understanding that the most pertinent evidence available has been presented.

\section{THE BENEFITS}

Arguing the benefits of the Admissibility and Transportation Loans is no easy feat, due to the lack of its documentation in academic literature, policy documents, and independent narratives. Nevertheless, there are four positives that can be associated with the repayment of these two loans. The first positive pertains directly to the government's finances: the money lent out is repaid in full with the addition of interest. According to the Government of Canada's Public Accounts, with the exception of 2010, each year the Immigration Loans Program appears to be accruing more money than it is lending. One recent $\mathrm{CIC}$ report estimated that the administrative costs of the Immigration Loans Program were $\$ 1.6$ million per year. Doing a rudimentary calculation subtracting the administrative costs from the gains and losses of the Immigration Loans, over the last ten years the government has accrued $\$ 1.08$ million. It should be cautioned, however, that this argument is becoming less compelling: if one only considers the last five years, it is shown that the government lent out $\$ 4.05$ million more than it brought in. The table below outlines these figures: 
Table 8.1: Rudimentary Calculation of Immigration Loans Program Financial Return

\begin{tabular}{lll}
\hline Year & $\begin{array}{l}\text { Amount Lent Out Each } \\
\text { Year (million) }\end{array}$ & $\begin{array}{l}\text { Cost of Immigration Loans Program } \\
\text { (Amount Lent Out Each Year Minus } \\
\$ 1.6 \text { million Administrative Costs) }\end{array}$ \\
\hline 2010 & $4,334,386$ & $5,934,386$ \\
2009 & $(735,718)$ & 864,282 \\
2008 & $(3,690,436)$ & $(2,090,436)$ \\
2007 & $(2,190,925)$ & $(590,925)$ \\
2006 & $(1,671,802)$ & $(71,802)$ \\
2005 & $(551,306)$ & $1,048,694$ \\
2004 & $(1,031,394)$ & 568,606 \\
2003 & $(3,692,773)$ & $(2,092,773)$ \\
2002 & $(3,722,083)$ & $(2,122,083)$ \\
2001 & $(4,126,939)$ & $(2,536,939)$ \\
\hline TOTAL & & $(1,088,990)$ \\
\hline Note. Created from GOC, Public Accounts 2001-2010 and CIC, 2011b, CIC evaluation of \\
Government-assisted refuges and resettlement assistant program, p. 62
\end{tabular}

A second positive result of loan repayments is that the money replenishes the Immigration Loans Program's fund, thereby enabling the monies to be re-lent to assist other refugee newcomers to

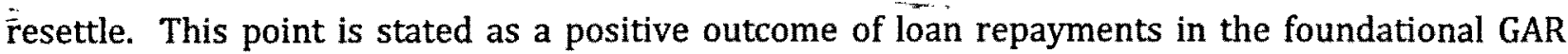
resettlement orientation manual (CIC, 2010c, p. 13).

A third positive of repaying the Immigration Loan is that the loan holders may develop the necessary skills to budget and manage finances in the Canadian context. This point predominantly speaks to the post-IRPA cohorts who are increasingly arriving from "protracted refugee situations" (Hyndman, 2009, p. 264), and who may have less familiarity with formalized economic institutions. One CIC survey found that only 5\% of GARs had previous knowledge of budgeting prior to arrival, and that only $1 \%$ knew how to open a bank account (CIC, 2011b, p. 54).

A final benefit to arise from repaying the Immigration Loans is a sense of pride. Although this is a likely sentiment, it is only overtly mentioned in one government publication (CIC, 2011b, p. 62). However, two related, and more commonly mentioned, feelings in the discourse are a gratitude for the opportunity to resettle in Canada and a true willingness to repay the loans; these comments are commonly couched in discussions of inabilities to meet payments (for example, Access Alliance, 2009, p. 3; CBC News Canada, 2007). 


\section{THE COSTS}

In contrast to the loans' benefits, the costs borne by loan holders are well documented by refugee advocates. There are three predominant actors arguing for the cessation of the Admissibility and Transportation Loans: the Canadian Council for Refugees, Access Alliance, and the Surrey Community in British Columbia.

\section{THE CANADIAN COUNCIL FOR REFUGEES (CCR)}

The Canadian Council for Refugees was established in 1978 as a nexus for those involved in refugee issues to network, advocate, and exchange information (CCR, 2011a). The council is adamant in its opposition of the Admissibility and Transportation Loans, which it merges into the single campaign entitled, "End transportation loans." The most substantive contribution that the CCR makes in critiquing the loan is a wide collection of personal narratives on its effects. In addition to publishing quotes on their website and posting interviews, testimonies, and seminars on YouTube ${ }^{13}$, the CCR also provides guidance on how people can take grassroots action.

In encouraging people to contact politicians through written postcards and letters they also provide some argumentation assistance. The arguments for ending the loans, which are echoed by Access Alliance and those in Surrey, can be grouped into the following: a concern with young people who are sacrificing their educations in pursuance of wages to repay the loans; that parents are unable to provide essential family supports because they are working multiple jobs; that refugee newcomers are already often dealing with trauma due to persecution and exile; that there may be long-term financial consequences for defaulting on loan payments; and that the loans are being paid at the cost of foregoing basic necessities (CCR, 2011c).

Although the CCR's above assertions are primarily based on anecdotal evidence, they should not be discounted. For instance, the first argument, that loan repayments are negatively impacting youths' educations, is a viable concern for two reasons. For one, although family members between the ages of 18 and 22 are considered family dependents on the principal resettlement application, these young adults are most often times assigned their own individual loans (CIC, 2010f, s. 13.1). What this means is that although older children and grandparents arrive on a single-family application,

13 Felix, 2011; Strategic Alliance for the Advancement of Immigrant Refugee Children and Youth, 2011 
members who are over the age of 18 usually receive separate loans. This likely contributes to why loan totals are often quoted as exceeding the $\$ 10,000$ per family cap (for example see CBC News Services, 2007).

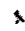

A second reason that the loans may inhibit these young adults' educations is due to the " $50 \%$ Additional Income Incentive Threshold." This stipulation states that Government-assisted refugees are allowed to "earn up to $50 \%$ of their total monthly RAP income support payment before any deduction is made to the[ir] monthly income support entitlement" (CIC, 2010e, s. 22). In other words, if a family's earned income exceeds $50 \%$ of the amount that they are receiving in monthly RAP financial assistance then the dollar-for-dollar amount over the $50 \%$ threshold is deducted from their total RAP monthly financial assistance amount.

The primary concern with this qualification arises from the caveat that any income earned by youth who are attending school full-time is excluded from the calculation of the family's total earnings. This point stands as an obvious root as to why so many young people are being documented by the CCR as both working and attending school full-time. It seems very likely that these youth and young adults are taking on greater amounts of the financial obligation in order to repay their own and their family's loans more quickly.

The second and third concerns of the CCR, that parents are unable to provide the necessary family supports and that the loans are compounding pre-existing traumatic stresses, exemplify the inherent challenges in evaluating migration policy. Throughout Ardittis and Laczko's (2008) edited volume, Assessing the Costs and Impacts of Migration Policy, researchers repeatedly referred to the complex and difficult nature of assessing migration policy For the purposes of this paper, the numerous challenges can be grouped into two types: data quality and accessibility, and issue complexity.

When conducting a cross-national comparison, the editors noted that the nations observed were similarly characterized by a lack of "...high quality, publically available data in the field of migration and asylum policy" (Ardittis \& Laczko, 2008, p. 196). In Canada's case, the government's insufficient disaggregation and publication of data has resulted in Government-assisted, Jointly Assisted, and privately sponsored refugees being clumped together into a single monolithic 
category of 'refugee'. This is problematic, for it limits Canadian researchers from making more acute statements on refugee newcomers' resettlement experiences.

To illustrate, according to Renaud, Piche \& Godin (2003), there are two schools of research on the economic integration of refugees into Canada. The first school compares and contrasts the economic performances across the three different immigrant categories. Researchers in this school generally agree that refugees have lower incomes and less prestigious jobs in comparison to economic and family migrants (Renaud et al, 2003). The second, more predominant, school focuses on the socio-economic inequalities that refugees face as a group. Arguments in this stream are rooted in low-income and under-employment figures, and focus on explaining the effects of institutional barriers, such as limited language proficiency, discrimination, and credential recognition (Krahn, Derwing, Mulder \& Wilkinson, 2000). It can be seen from these two schools that neither disaggregates the refugee groups by their initial resettlement experiences or sponsorship types. The result is a widening gap in the understanding refugee newcomer's integration into Canada (Yu, Ouellet \& Warmington, 2007).

The second challenge identified in this edited volume is the complexity of migration issues. McKinley (2008), keenly notes that,

When migrants arrive, a country does not simply get labour units, it gets people and often their families too, with all the complexity that this entails. Migration raises issues of identity, social cohesion and social interaction both for the host community and migrants themselves (p. 5)

Bonin, Roberts, and Zimmermann (2008) concur and note that sometimes immigration objectives and elements are simply unquantifiable (p. 146). The CCR's concern, that the overworking of parents in order to repay the Immigration Loans is resulting in diminished family supports, is an example of a migration issue that is virtually impossible to quantify. For instance, what would constitute a family support and how would it be measured? If it were to be measured in hours, what would a 'sufficient' amount of time be? How would "together" be defined: Would being in the same house qualify, or would persons have to be in the same room, or perhaps sharing an activity?

Simply put, families of any culture or country are too diverse in their compositions and conceptions of "family support" to be reduced to a numerical value. Van Selm (2008) importantly reminds the volume's readers that although migration policy oftentimes feels too complicated to be evaluated, there do exist various aspects that are evaluable (p. 102). Although this fact is often discounted in 
today's quest for hard and quantifiable data, a great portion of migration policy's evaluation data is necessarily procured through qualitative methodologies.

\section{ACCESS ALLIANCE}

Access Alliance is a Service Providing Organization in Toronto that provides multicultural health and community services (Access Alliance, 2011a). To date, this organization is credited with publishing the most comprehensive research findings, based on qualitative research, regarding the mental health effects of repaying the Transportation Loan on Government-assisted refugees. Access Alliance's research department is distinguishable because it works upon the two models of Social Determinants of Health and Community Based Research. The Social Determinants of Health perspective conceptualizes health beyond the provision of medical services for those who are ill; it seeks, rather, to identify and examine the key determinants of health. Access Alliance's research projects look at various socio-economic determinants of health, such as employment, income security, social support, and access to services. It was in this spirit that they partnered with the Centre for Addiction and Mental Health to conduct exploratory research on the mental health issues being faced by newly arrived Government-assisted refugees (Access Alliance, 2009).

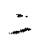

The second strength of Access Alliance's research is its commitment to Community Based Research (CBR). The goal of CBR is to affect positive social change by engaging community members to participate as research collaborators and agents of change, as opposed to mere "research subjects" (Access Alliance, 2011b). Five community peer researchers, and numerous service providers and academics conducted research on the Impacts of Transportation Loan Repayments on Governmentassisted Refugees in Toronto (Access Alliance, 2009). Focus groups and interviews with GARs from Afghan, Karen, and Sudanese communities yielded four key findings.

The first finding was that repaying the Transportation Loan was a major cause of mental duress, as respondents cited feelings of worry, stress, and anxiety (Access Alliance, 2009, p, 2). The researchers noted that the repayments were exacerbating the multiple mental health issues that GARs already face. This is an exceptionally important point. Sight of the circumstances from which people flee and seek refuge in Canada is oftentimes forgotten after arrival, as immediate integration factors tend to take precedence.

When considering refugees' mental health issues, it is important to understand that refugees who 
arrive into Canada have endured at least three sequential traumatic stages: war, violence, forced labour, family separation and targeted persecution in their country of origin (Wilson, Murtaza \& Shakya, 2010, p. 46); numerous risks and obstacles while in transit to a safe country (Gong-Guy, Cravens, \& Patterson, 1991, p. 642); and a distressing period of "statelessness" either in a protracted refugee camp situation, or while awaiting to be granted official protected person status in Canada (Wilson et al., 2010, p. 46).

These three stresses tend to amalgamate together and result in substantial impacts on the mental wellbeing of refugees. To demonstrate, according to a 2003 study conducted on the mental health of Tamil refugees in Toronto, one-third of the 1,600 participants had directly witnessed a traumatic event such as rape, physical assault, or combat (Beiser, Simich, \& Pandalangat, 2003, p. 240). Similarly, broader clinical studies have found high rates of post-traumatic stress disorder (PTSD) ranging from $39 \%$ to $100 \%$ varying across refugee groups (UNHCR, 2002, p. 233). Both of these rates are substantially higher than the $1 \%$ rate of PTSD found among the general population. Additionally, these clinical studies also found that rates of depression were between $47 \%$ and $72 \%$. Over recent years, Canada's immigrant service providing organizations have noted an increase of incoming GARs where specialized medical care is required for survivors or trauma and/or those with mental health conditions [CIC, 2011b, p. 51)

Access Alliance's second finding uniquely highlighted that GARs had signed their contractual loan obligations "out of vulnerability and desperation rather than through informed choice" (Access Alliance, 2009, p. 2). The researchers argue that this nature of signing is inconsistent with Canada's lending policies. Furthermore, they also argued that this vulnerability continues to be perpetuated after loan holders' arrivals into Canada because loan holders constantly fear that defaulting on their payments would jeopardize their citizenship applications, or that they might be deported. Although these fears cannot legally come to pass, the high levels of emotion and doubt that these individuals' feel are sanctioned by their life experiences with political institutions outside of Canada.

The third finding, which is also not identified elsewhere, is the social stigma that some cultural communities (particularly Muslim) attach to being in debt (Access Alliance, 2009, p. 3). Members of the Afghan community indicated that the loans had had a stigmatizing impact on them, and that given the choice, they would not have taken on the loans. Whether the participants would have preferred to stay in Afghanistan rather than take the loans, or come to Canada with a different 
financial arrangement is not made clear. Access Alliance's last finding focused on the economic aspect. They found that making loan repayments is effectively undercutting "the already low levels of income (or social assistance) that GARs receive, thereby worsening the poverty and economic risk that they face" (Access Alliance, 2009, p. 3). This particular cost is similarly documented by advocates in Surrey and will be further explored in the next section.

\section{SURREY, BRITISH COLUMBIA}

Refugee advocates and the City of Surrey in British Columbia have come together to orchestrate the most comprehensive political campaign against the Assistance and Transportation Loans. Reiterating the exact same costs to successful integration as the Canadian Council for Refugees (impact on youth's educations, negating family supports, exacerbating pre-existing mental health issues, long-term financial consequences, and foregoing basic necessities), these groups are calling on the Federal government to cancel all outstanding Assistance and Transportation Loans and for their complete termination (City of Surrey, 2010; First Call, 2009).

The grassroots coordination of these efforts can be traced back to First Call, which is British Columbia's Child and Youth Advocacy Coalition. This cross-sectoral coalition, which began in response to Canada's ratification of the United Nations' Convention on the Rights of the Child in 1992 , has grown to encompass partnerships with over ninety provincial, regional, and community organizations and individuals (First Call, 2008b, 2008c). The coalition's interest in the Transportation Loans stems from their drive to eliminate child poverty, and the fact that one in two children in recently arrived immigrant families are poor (First Call, 2008a). In an open letter, the coalition argues that the Transportation Loan is a bad public policy because it both diminishes Canada's compassionate intentions in accepting people for resettlement, and because it represents a false savings for government and society.

Framing the Assistance and Transportation Loans as false savings is apt because it encompasses both a short and long-term view of the loans' costs. Essentially, any integration challenges that derive from the sacrifices made in repaying the Immigration Loans are ultimately balanced as deficits for Canada. Evidence that the Assistance and Transportation Loans are impeding integration can be found in the simple fact that GARs are facing difficulties in providing for their basic needs. The CIC GAR/RAP evaluation (2011) has found that $57 \%$ of GARs use food banks, that 
$61 \%$ expressed difficulty in repaying their Transportation Loans, and that 33\% cited financial issues as the greatest difficulty in their resettlement (p. 9 \& p. 58),

Additionally, several reports have found that provincial income assistance rates, which RAP payment rates are pegged to, are benchmarked at inappropriately low levels (CIC, 2011b, p. 57). In fact, CIC's income support has been calculated to equal less than one-half of the income required to meet the Low Income Cut-Off (LICO) level in Canada (p. 10). Twenty-nine percent of GARs surveyed said that RAP income support was insufficient to cover basic needs like food, clothing, and housing (p. 58). This inadequacy of the RAP is unsurprising, for it has not changed since its creation in 1998 (Pressé \& Thompson, 2009, p. 97). One major contention with the too low-RAP incomeassistance rate is that it does not factor in the Admissibility and Transportation Loan payments that refugees must make each month (CIC, 2011b, p. 60).

There is evidence that GARs are having difficulty in repaying their Immigration Loans. Of the 20052009 GAR cohort, $36 \%$ were simply not paying, $8 \%$ had the loans written-off, and $1 \%$ had their loans deferred (CIC, 2011b, p. 62). It is significant that almost half (44\%) of recently arrived GARs were unable to make their loan repayments and had to seek alternative solutions. Refugee advocates argue that this impoverishment further marginalizes refugee families and impedes their integration (First Call, 2008a.)

This paper has repeatedly discussed the changes that IRPA has brought to the profile of refugees arriving into Canada for resettlement. Before the act was implemented, refugees, primarily European-based political dissidents, were selected based upon their potential to quickly adapt and contribute to the Canada (Pressé \& Thompson, 2009, p. 96). In contrast, today's refugees are increasingly arriving from "protracted refugee situations" in Africa, Asia, and the Middle East. Protracted refugee situations are defined by the UN as when 25,000 or more refugees from the same nationality are in exile for five years or longer in any country of asylum (UNHCR, 2011a). The organization goes further to state that in protracted refugee situations

[B] asic rights and essential economic, social and psychological needs remain unfulfilled after years in exile. A refugee in this situation is often unable to break free from enforced reliance on external assistance" (p 41).

Canada has made international commitments to address the growing instances of people living in protracted refugee situations (CIC, 2010a, p. 11). At the High Commissioner's Dialogue on 
International Protection in 2009, Canada agreed to resettle 5,000 of the 100,000 Bhutanese refugees who have been living in Nepalese camps for almost twenty years (CIC, 2010a, p. 7). Additionally, in 2009, 4,000 Iraqi refugees were resettled across Canada.

It is anticipated that GARs will continue to encounter a number of integration challenges due to the increased number of those who are arriving with 'integration barriers.' CIC has identified the following in a comparison of the 2000 and 2009 GAR cohorts: people without skills in either official language have increased by $14 \%$, those without formal education has increased $26 \%$, and levels of those arriving over the age of 65 have increased by $150 \%$ (CIC, 2011b, p. 8). The outcomes of these challenges are beginning to become evident in employment figures.

CIC's analysis of the Immigrant Database found that GARs who have arrived over the last five years are averaging an unemployment rate of $25 \%$, and that about $40 \%$ of GARs were unemployed three years after arrival (p. 10). Additionally, of those who had managed to secure employment, their wages were found to be relatively low: average earnings one year after arrival were $\$ 11,700$, and after five years they had increased to $\$ 21,700$ (p. 10). These employment outcomes affect the abilities of refugee newcomers' to strongly establish themselves in Canada.

Lastly, refugee advocates cite a strong wariness owing to a belief that defaulting on loan repayments may have long-term emotional and financial consequences for loan holders. In addition to the previously mentioned barrier to sponsoring family members, there is also a fear that those who default on their loans may be denied future access to mortgages and/or educational loans (First Call, 2009). These long-term implications are an example of what is not yet fully understood of the post-IRPA cohorts (Hyndman, 2009, p. 248).

In sum, refugee advocates have forwarded the argument that Assistance and Transportation Loan repayments constitute a false savings for the government and society. The integration of GARs is impeded by insufficient RAP payment amounts that do not budget for loan repayments in their monthly allotments. GARs are further challenged in the long-term by their inabilities to obtain employment, due to factors, such as their arriving from protracted refugee situations and possessing a minimal knowledge of either official language. Although GARs employment prospects improve over time and become equivalent to those of PSRs after six years (CIC, 2011b, p. 65 \& 67), advocates argue that abundant sacrifices must initially be made in order to meet loan repayments. 
The City of Surrey has been extremely effective at harnessing these arguments and presenting them to the public. In striving to have the Admissibility and Transportation Loans terminated, the city has forwarded their arguments to both the Union of British Columbia Municipalities (UBCM), and the Federation of Canadian Municipalities (FCM) (City of Surrey, 2010). Both parties adopted the resolution (FCM, 2010; UBCM, 2009), and the three bodies are currently lobbying the Canadian government to terminate the two loans and to cancel any outstanding debts.

\section{THE FUTURE OF THE ADMISSIBILITY AND TRANSPORTATION LOANS}

At the time of writing, CIC Minister Jason Kenney has stated that the loans will not be terminated (Saunders \& Kusch, 2010); however, there is currently a internal review being conducted to assess the impacts of the Admissibility and Transportation Loans on GAR's integration (CIC, 2011b, p. 16). The government is aware that the number and nature of barriers facing GARs has increased since the implementation of IRPA and that resettlement programming must be adjusted to meet these changes (CIC, 2011b, p. 80; Pressé \& Thompson, 2009, p. 96). 
This paper was written with two objectives in mind: to, firstly, create a document that thoroughly and coherently explained the Immigration Loans Program; and secondly, to examine the policy appropriateness of the Admissibility and Transportation Loans post-IRPA. The first objective arose during the preliminary research process when it became evident that neither side of the discourse was comprehensively addressing the loan's effects on refugees. On the one hand, refugee advocates were collecting and disseminating narratives of people's tribulations in repaying their loans, but often without conceding that thousands of refugees do manage to repay their loans within the allotted timeframe. On the other hand, government publications tended to treat the issue in a calculating and bureaucratic fashion that was noticeably devoid of refugees' lived experiences.

Research has been presented from historical and academic literature, policy documents, and personal narratives, in order to comprehensively examine the Immigration Loans Program. Readers have been shown how Canada's relationship with refugees has grown slowly, but become increasingly humanitarian over the last century. Canada's refugee system has also been explored, as was the structure of the Immigration Loans Program. The second half of the paper focused on presenting the effects of the loans on refugees. An international comparison showed how Canada is alone in recouping both admissibility and transportation costs from its resettling refugees, and in charging interest. Also, the loans' discourse was clarified through an explanation of the Admissibility and Transportation Loans' conflation, and of how the loans affect refugees differently depending on their sponsorship arrangements. Lastly, the financial details were outlaid, as were the costs and benefits of repaying the loans. Through this exercise the author concludes that the Admissibility and Transportation Loans are no longer an appropriate policy mechanism, and that they should be eliminated for two reasons.

Firstly, repayment of these two loans should end because they are no longer appropriate for assisting post-IRPA loan holders. Sixty years ago, when the Transportation Loan began as the Assisted Passage Loan, it was a mechanism for hastening the arrival of British migrants who were able to immediately find employment and begin repaying their loans. As the years passed and the profile of the loan holders changed, the loan maintained its relevancy, as Canada continued to prioritize the selection of refugees who could most readily integrate and contribute to the Canadian economy. Implementation of the Immigration and Refugee Protection Act in 2002 changed all of this. 
IRPA's shift away from the pragmatic selection of refugees, towards the more humanitarian selection of those in the greatest need of protection was a tremendous and compassionate step for Canada. The result has been a substantial change in the composition and needs of refugees arriving to Canada for resettlement. Although the extent of integration challenges that the most recent cohorts are experiencing is not yet fully understood, it is unquestionable that the level of barriers has increased.

To demonstrate, recent GAR cohorts are documented in the literature as being in possession of lower levels of English and French proficiencies, as well as lower levels of formal education. These two factors have been shown to hinder both social and financial integration. Additionally, the instances of people arriving with mental health issues are increasing, as more cohorts are arriving from protracted refugee situations.

In regards to more quantitatively measurable integration challenges, low levels of employment and income earnings are increasingly being identified. The fact that $57 \%$ of GARs use food banks, $61 \%$ expressed difficulty in repaying their Transportation Loans, and that $33 \%$ cited financial issues as the greatest difficulty in their resettlement is evidence of employment and income challenges (CIC, 2011b, p. 9 \& 58). As well, in the last five years, almost half of loan holders have been unable to make their repayments, and have either defaulted or sought repayment alternatives. Although it is true that over one-half of loan holders are able to make their loan repayments on time, the costs to young peoples' educations, and the additional strain on family units have been identified in the qualitative literature.

The second, more speculative, reason why the Admissibility and Transportation Loans should be eliminated are because they are increasingly less in line with Canada's best financial interests. Over the last ten years, the Immigration Loans Program appears to have only brought in $\$ 1.08$ million more than it lent out (author's calculation). And, if only the last five years are considered, the government lent out $\$ 4.05$ million more than it brought in (also author's calculation). The costs are further heightened with the addition of the, so far, incalculable costs of long-term integration barriers. It is reasonable to assume that the increasingly low Immigration Loan repayment and interest revenues, in combination with the long-term costs of financially-hampered integration, ultimately results as a deficit for Canada. 
Unfortunately, the present economic recession has created a cautlonary spending environment wherein the outright cancelation of the Admissibility and Transportation Loans in the near future is unlikely. Nevertheless, the government has the potential to ease the financial burden of repaying the Immigration Loans in two simple ways. Firstly, the commencement of the loan repayments can be delayed for at least one year after arrival. Doing so would enable newcomer refugees to Invest their time and money into themselves and families, thereby establishing stronger foundations for their new lives in Canada. The second way that the government can lessen refugees' integration barriers is by eliminating the collection of interest on the loans. This interest was Initially added to the loans in 1995 during a similar period of economic uncertainty, and although revenue is made, it is increasingly less advantageous. Since the implementation of IRPA, the revenue collected from the loans' interest is decreasing each year, while the integration challenges of newcomer refugees continue to increase.

This paper has sought to bring together various opinions on the Immigration Loans Program; however, there are numerous areas that can be further explored. For instance, future studies may be conducted to qualitatively and systematically document the experiences that different refugee groups are having with their Immigration Loans. For example, how does racial discrimination affect loan holders of different cultural backgrounds? Is it easier for single males, or females to pay off their loans? Or perhaps, how many refugee youth are both working and studying full-time? How do they describe the effects of these circumstances? Or, how does the stress of making monthly payments affect those suffering from post-traumatic stress disorder? And how does that impact their integration? Additionally, the qualitative analysis of this loan program can be intensified if the government is able to further disaggregate the refugee types and the repayment details for publication.

In sum, the circumstances under which the Admissibility and Transportation Loans were legitimate have ended. The IRPA shifted Canada's resettlement objectives in a more humanitarian direction, and the Admissibility and Transportation Loans are evidence of a refugee policy that has not adapted to this change. If these two loans are to realistically be eliminated, then it must be proven to both policy makers and the public that the costs of continuing with them outweigh the benefits. In face of the facts, the costs have clearly presented themselves as dominating. 


\section{REFERENCES}

Abella, I. \& Troper. H. (1991). None is too many (3rd ed.). Toronto, ON: Lester Publishing Limited.

Access Alliance. (2009). Impact of transportation loan repayment required on Government Assisted Refugees (GARs) in Toronto (Summary of Research Findings) Retrieved December 29, 2010, from http://www.ccrweb.ca/documents/accessalliance_ summary_transportation_loans.pdf

(2011a). About Access Alliance. Retrieved August 19, 2011, from http://accessalliance.ca/about

-..... (2011b). What is community based research? Retrieved August 19, 2011, from http://accessalliance.ca/research/approach/cbr

Ardittis, S. \& Laczko, F. (Eds.). (2008). Assessing the costs and impacts of migration policy: An international comparison. Geneva: International Organization for Migration and Eurasylum.

Beiser, M., Simich, L. \& Pandalangat, N. (2003). Community in distress: Mental health needs and help-seeking in the Tamil Community in Toronto. International Migration 41(5), p. 233-245.

Bonin, H., Roberts, R. \& Zimmermann, K. F. (2008). Comparing and evaluating public expenditure on migration. In S. Ardittis \& F. Laczko (Eds.). Assessing the costs and impacts of migration policy (p. 137-190). Geneva: International Organization for Migration and Eurasylum.

Canadian Council for Refugees. (2011a). About the CCR. August 17, 2011, from http://ccrweb.ca/en/about-ccr

(2011b). End the burden of refugee transportation loans! Retrieved July 30, 2011, from http://ccrweb.ca/en/transportation-loans

-----. (2011c). Letters to Ministers. Retrieved August 18, 2011, from http://ccrweb.ca/en/option-2letters-ministers 
Canadian Unitarian Council. (2005). Becoming a refugee sponsor under the sponsorship agreement of the Canadian Unitarian Council [Guide for Congregations]. Retrieved March 1, 2011, from www.cuc.ca/social_responsibility/sponsorship_agreement.pdf

CBC News Canada. (27 December, 2007). Ottawa criticized for charging refugees for flights:

Newcomers find it difficult to pay government back, says immigrant services group. Retrieved February, 28, 2011, from http://www.cbc.ca/news/canada/britishcolumbia/story/2007/12/27/bc-refugeebills.html

Chimni, B. S. (2009). The birth of a 'Discipline': From refugee to forced migration studies. Journal of Refugee Studies 22(1), p. 11-29.

Citizenship and Immigration Canada. (2005a). Report on financial administrative controls of the Immigration Loans Program. Retrieved July 21, from http://www.cic.gc.ca/english/resources/audit/ilp.asp\#f

-..-. (2005b). Report on the evaluation of Canada's membership in the International Organization for Migration. Retrieved July 10, 2011, from http://www.cic.gc.ca/english/resources/evaluation/loM/program.asp

(2007a). Refugees: Refugee claims in Canada - Options for refused applicants. Retrieved July 15, 2011, from http://www.cic.gc.ca/english/refugees/inside/refusals.asp

-..-. (2007b). Summative evaluation of the private sponsorship of refugees program. Retrieved July 16, from http://www.cic.gc.ca/english/resources/evaluation/psrp/psrpsummary.asp\#summary

-.-. (2008). IR 5: Immigration cost recovery [Reference Manual]. Retrieyed July 5, 2011, from http http://www.cic.gc.ca/English/resources/manuals/ir/index.asp

-.-.-. (2009a). OP 5: Overseas selection and processing of Convention Refugees Abroad Class and members of the Humanitarian-Protected Persons Abroad class [Operation Manual]. Retrieved July 6, 2011, from http://www.cic.gc.ca/English/resources/manuals/op/index.asp 
(2009b). Resettlement from outside Canada: After applying. Retrieved July 8, 2011, from http://www.cic.gc.ca/english/refugees/outside/apply-after.asp

(2010a). Annual report to Parliament on immigration (Annual Report). Retrieved March 1, 2011, from http://www.cic.gc.ca/english/resources/publication s/annualreport2010/index.asp

-.-.. (2010b). Departmental performance report: For the period ending March 31, 2010. Retrieved June 25, 2011, from http://www.tbs-sct.gc.ca/dpr-rmr/2009-2010/inst/imc/imc00eng.asp

-.--. (2010c). Facts and figures 2009 - Immigration overview: Permanent and temporary residents. Retrieved March 8, 2011, from http://www.cic.gc.ca/english/resources/statistics/facts2009/permanent/06.asp

----. (2010d). First steps: An orientation package for newcomers. Retrieved July 25, 2011, from http://www.settlement.org/downloads /First_Steps_English.pdf

---.. (2010e). IP 3: In Canada processing of Convention Refugees Abroad and members of the Humanitarian-Protected Persons Abroad classes (Operational Manual: Parts I, II, III, IV, and Appendices). Retrieved June 9, 2011, from http://www.cic.gc.ca/English/resources/manuals/ip/index.asp

---.. [2010f). OP 17: Loans [Operation Manual]. Retrieved March 15, 2011, from http://www.cic.gc.ca/English/resources/manuals/op/index.asp

----. (2010g). PPI: Processing claims for refugee protection in Canada (Operation Manual). Retrieved July 16, 2011, from www.cic.gc.ca/english/resources/manuals/pp/pp01-eng.pdf

-.-.-. (2010h). Strategic outcomes and program activity architecture: Program activity 4-Refugee program. Retrieved February 26, 2011, from http://www.cic.gc.ca/english/department/paa/activity-04.asp 
-.-.-. (2011a). Canada welcomes highest number of legal immigrants in 50 years while taking action to maintain the integrity of Canada's immigration system [News Brief]. Retrieved July 17, 2011, from http://www.cic.gc.ca/english/department/media/releases/2011/2011-0213.asp

--.-. (2011b). CIC evaluation of Government-assisted refugees and resettlement assistant program [Final Evaluation Report]. Ottawa: Author.

-...... (2011c). Notices and proposed regulations: Regulations amending the Immigration and Refugee Protection Regulations (Vol. 145, No. 12). Retrieved March 18, 2011, from http://www.gazette.gc.ca/rp-pr/p1/2011/2011-03-19/html/reg3-eng.html

-.-. (2011d). Summary tables: Permanent and temporary residents, 2010. Retrieved February 13, 2011, from http://www.cic.gc.ca/english/resources/statistics/facts2010-summary/01.asp

----. (2011e). The refugee system in Canada. Retrieved July 14, 2011, from http://www.cic.gc.ca/english/refugees/canada.asp

City of Surrey. (2010). Refugee housing study: Advocacy to terminate the Transportation Loan program for refugees. Retrieved August 20, 2011, from http://www.surrey.ca/plansstrategies/3173.aspx

Department of Foreign Affairs and International Trade. (1955, November 15). Financial measures to assist immigration [Cabinet Document 228-55]. Retrieved July 4, 2011, from http://www.international.gc.ca/department/history-histoire/dcer/detailsen.asp?intRefld $=1578$

Department of Justice. (1994). Debt write-off regulations. Retrieved August 1, 2011, from http://laws-lois.justice.gc.ca/eng/regulations/SOR-94-602/page-1.html

Federation of Canadian Municipalities. (2010). Termination of the Transportation Loan program for refugees [Letter to the Minister]. Retrieved August 21, 2011, from http://www.surrey.ca/plans-strategies/3173.aspx 
Felix, R. (2011, January 26). Burden of refugee transportation loans [Video file, Parts I \& II]. Video posted to http://www.youtube.com/user/SPHUofA\#p/u/4/-r1qqbg3YiM

First Call, BC Child and Youth Advocacy Coalition. (2008a). Campaign to repeal refugee Transportation Loan requirements [Open Letter]. Retrieved August 20, 2011 from http://www.firstcallbc.org/pdfs/economicequality/3-refugee\%20loans.pdf

-.... (2008b). Coalition partners. Retrieved August 20, 2011, from http://www.firstcallbc.org/about-coalitionPartners.html

-.--.. (2008c). History. Retrieved August 20, 2011, from http://www.firstcallbc.org/abouthistory.html

---.. (2009). Canada's refugee Transportation Loan Program: Survey and request for assistance [Public Letter]. Retrieved August 20, 2011, from http://www.firstcallbc.org/pdfs/EconomicEquality/3refugee $\% 2010 a n \% 201$ tr\%20to\%20MPs.pdf.

Francis, R. D., Jones, R. \& Smith, D. B. (2000). Destinies: Canadian history since Confederation (4th ed.). Scarborough, ON: Nelson Thomson Learning.

Gong-Guy, E., Cravens, R. B. \& Patterson, T. E. (1991). Clinical issues in mental health service delivery to refugees. American Psychologist 46(6), 642-648.

Government of Canada. (2010). Public accounts of Canada, 2001 - 2010 [Volumes I \& II]. Retrieved June 25, 2011, from http://epe.lacbac.gc.ca/100/201/301/public_accounts_can/index.html

Hardy, C. \& Phillips, N. (1999). No joking matter: Discursive struggle in the Canadian refugee system. Organizational Studies 20(1), p. 1-24. 
Hiebert, D. (2009, September). The economic integration of immigrants in Metro Vancouver (CERIS Working Paper Series No. 09 - 08). Retrieved January 29, 2011, from http:// mbc.metropolis.net/assets/uploads/files/wp/2009/WP09-08.pdf

Holmes, J. W. (1979). The shaping of peace: Canada and the search for world order 1943-1957 (Volume 1). Toronto, ON: University of Toronto Press.

Hyndman, J. (2009). Second-class immigrants or first class protection? Resettling refugees to Canada. In P. Bevelander, M. Hagström, \& S. Rönnqvist (EDs.). Resettled and included?: The employment integration of resettled refugees in Sweden (p. 247-266). Sweden: Malmo University. Online Publication. Retrieved July 30, 2011, from http://195.178.227.4/bitstream/handle/2043/9154/Resettled\%20and\%20Included\%20 MUEP.pdf?sequence $=2$

Immigration and Refugee Protection Act. (2001). Retrieved February 24, 2011, from http://laws.justice.gc.ca /en/i-2.5/index.html

Immigration and Refugee Protection Regulations. (2001). Retrieved June 9, 2011, from http://laws-lois.justice.gc.ca/eng/regulations/sor-2002-227/page-1.html

International Organization for Migration. (2010). United States of America: Facts and figures.

Retrieved July 24, from http://www.iom.int/jahia/Jahia/united-states-of-america

----. (2011a). Concession fares. Retrieved July 18, 2011, from, http://www.iom.int/jahia/Jahia/pid/1820

. (2011b, February). The International Organization for Migration in brief. Retrieved March 1, 2011, from http://www.iom.int/jahia/webdav/site/myjahiasite/shared/shared/mainsite/published_d ocs/books/iomfolder_eng/iom_in_brief_en.pdf

Jones, M. \& Baglay, S. (2007). Refugee Law. Toronto: Irwin Law 
Kelley, N. \& Trebilcock, M. (2000). The making of the mosaic: A history of Canadian immigration policy (Reprinted). Toronto, ON: University of Toronto Press.

Knowles, V. (2007). Strangers at our gates: Canadian immigration and immigration policy, $1540-$ 2006 (Revised ed.). Toronto, ON: Dundurn Press.

Krahn, H., Derwing, T., Mulder. \& Wilkinson, L. (2000). Educated and underemployed: Refugee integration into the Canadian labour market. Journal of International Migration and Integration 1(1), pp. 59-84.

McKinley, B. (2008). Preface. In S. Ardittis \& F. Laczko (Eds.). Assessing the costs and impacts of migration policy (p. 5-6). Geneva: International Organization for Migration and Eurasylum.

Orr, B. (2004). Resettlement: A durable solution. Canadian Issues, March, p. 22-24.

Pressé \& Thompson. (2008). The resettlement challenge: Integration of refugees from protracted refugee situations. Refuge 25(1), p. 94-99.

Public Works and Government Service Canada. (2010, September 15). Receiver General for Canada. Retrieved July 27, 2011, from http://www.tpsgc-pwgsc.gc.ca/apropos-about/fi-fs/rgeng.html\#accounts

Refugee Sponsorship Training Program. (2011). Sponsorship agreement holders \& their constituent groups [Sponsoring Group Handbook]. Retrieved March 2, 2011, from http://www.rstp.ca/index.php?option=com_content\&view=article\&id=204\&Itemid=242\&la $\mathrm{ng}=\mathrm{en}$

Renaud, J., Piche, V. \& Godin, J. (2003). “One's bad and the other one's worse”: Differences in economic integration between asylum seekers and refugees selected abroad. Canadian Ethnic Studies Journal 35(2), 85, 101. 
Strategic Alliance for the Advancement of Immigrant Refugee Children and Youth. (2011). Hidden costs: Paying back the refugee transportation loan [Video file, Parts I \& II]. Video posted to http://www.youtube.com/watch?v=UDQW6qJYZ74

Sanders, C. \& Kusch. L. (2010, April 9). Kenney willing to tweak refugee reform bill. Winnipeg Free Press. Retrieved May 27, 2011, from http://www.winnipegfreepress.com/local/kenney-willing-to-tweakrefugee-reform-bill-90335289.html

Union of British Columbia Municipalities. (2009). Termination of the Transportation Loan program for refugees [Resolution]. Retrieved August 21, 2011, from http://www.surrey.ca/plansstrategies/3173.aspx

United Nations High Commissioner for Refugees. (1967). Convention and protocol relating to the status of refugees (Resolution 2198 (XXI)). New York, NY: United Nations.

-.-... (2002). Refugee resettlement: An international handbook to guide reception and integration. Retrieved August 20, 2011, from http://www.unhcr.org/cgibin/texis/vtx/home/opendocPDFViewer.html?docid=3d98623a4\&query=\%20An\%20Inter national\%20Handbook\%20to\%20guide\%20reception\%20and\%20integration

(2011a). UNHCR global trends 2010 (Annual Report). Retrieved July 16, 2011, from http://www.unhcr.org/cgi-bin/texis/vtx/home/opendocPDFViewer.html?docid $=4 \mathrm{dfa} 11499$ \&query $=$ global $\% 20$ trends

-.-.-. (2011b). UNHCR note on conventional travel documents and ICAO standards. International Journal of Refugee Law 23(1), p. 133-140.

(2011c). UNHCR resettlement handbook (Revised, Part I and Country Chapters). Retrieved July 15, 2011, from http://www.unhcr.org/4a2ccf4c6.html

U.S. Department of State. (2011). The U.S. Refugee Admissions Program. Retrieved July 16, 2011, from http://www.state.gov/g/prm/c26471.htm 
Van Selm, J. (2008). How is migration policy evaluated? In S. Ardittis \& F. Laczko (Eds.). Assessing the costs and impacts of migration policy (p. 21-107). Geneva: International Organization for Migration and Eurasylum.

Wilson, B.G. (1988). Colonial identities: Canada from 1760 to 1815. Ottawa, ON: National Archives of Canada.

Wilson, R. M., Murtaza, R. \& Shakya, Y. B. (2010). Pre-Migration and post-migration determinants of mental health for newly arrived refugees in Toronto. Canadian Issues Summer, p. 45-50.

Yu, S., Ouellet, E. \& Warmington, A. (2007). Refugee integration into Canada: A survey of empirical evidence and existing services. Refuge 24(2), 17-34.

Zetter, R. (2007). More labels, fewer refugees: Remaking the refugee label in an era of globalization. Journal of Refugee Studies 20(2), p. 172-192. 